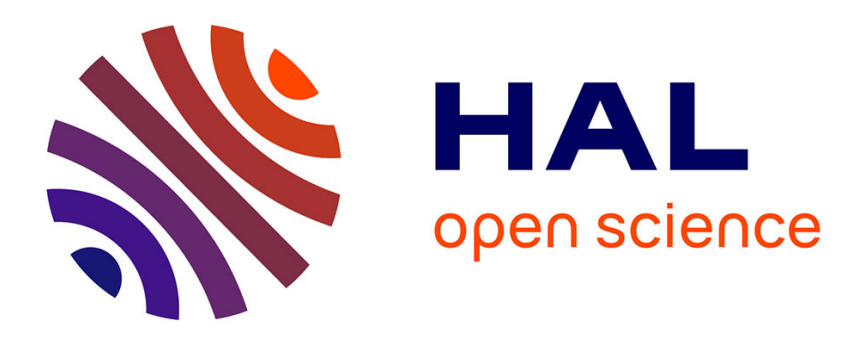

\title{
Effects of a polydisperse cloud on tropospheric chemistry
}

\author{
N. Audiffren, N. Chaumerliac, M. Renard
}

\section{To cite this version:}

N. Audiffren, N. Chaumerliac, M. Renard. Effects of a polydisperse cloud on tropospheric chemistry. Journal of Geophysical Research: Atmospheres, 1996, 101 (D20), pp.25949 - 25965. 10.1029/96JD01548. hal-01819424

\section{HAL Id: hal-01819424 \\ https://hal.uca.fr/hal-01819424}

Submitted on 6 Feb 2021

HAL is a multi-disciplinary open access archive for the deposit and dissemination of scientific research documents, whether they are published or not. The documents may come from teaching and research institutions in France or abroad, or from public or private research centers.
L'archive ouverte pluridisciplinaire HAL, est destinée au dépôt et à la diffusion de documents scientifiques de niveau recherche, publiés ou non, émanant des établissements d'enseignement et de recherche français ou étrangers, des laboratoires publics ou privés. 


\title{
Effects of a polydisperse cloud on tropospheric chemistry
}

\author{
N. Audiffren, N. Chaumerliac and M. Renard \\ LaMP, Laboratoire de Météorologie Physique, CNRS and Université Blaise Pascal, Aubière, France
}

\begin{abstract}
Effects of a polydisperse cloud on tropospheric chemistry have been studied in the framework of a two-dimensional model where dynamical, microphysical, and chemical processes are fully interactive. The chemical module describes the tropospheric photochemistry of ozone precursors in both gaseous and aqueous phases for a remote atmosphere. Impacts of the cloud polydisperse feature have been obtained by comparing the results in the case of a monodisperse cloud created under the same meteorological conditions. The $[\mathrm{NO}] /\left[\mathrm{NO}_{2}\right]$ ratio decreases more sharply in the case of the polydisperse cloud. The partitioning of the most soluble species does not follow the Henry's law equilibrium except in the middle of the cloud. This result has implications for airborne measurements made within clouds. Deviations from Henry's law found in samples are usually explained only by the effect of variations of the liquid water content with time, assuming that no real deviations exist in the real cloud. Here, it is shown that deviations from Henry's law equilibrium may exist even for clouds consisting of small droplets.
\end{abstract}

\section{Introduction}

Radicals $\left(\mathrm{HO}_{\mathrm{x}}, \mathrm{RO}_{2}\right)$ are at the heart of the atmospheric photochemical oxidant cycle. $\mathrm{OH}$ is the primary oxidant of the troposphere and thus plays a key role in the cycles of many important gases. The chemistry of odd-hydrogen radicals $\left(\mathrm{HO}_{\mathbf{x}}\right)$ is closely linked to that of organic peroxy radicals $\mathrm{RO}_{2}$ through their interconversion reactions $\mathrm{(OH}$ and $\mathrm{CO}, \mathrm{OH}$ and methane). In addition, hydroxyl radical and peroxy radicals $\left(\mathrm{HO}_{2}\right.$ and $\mathrm{RO}_{2}$ ) affect the photostationary state balance of NO and $\mathrm{NO}_{2}$ which control the net ozone production in the troposphere.

Clouds modify the fate of these radicals (as well as for other chemical species) by partitioning them between gas and aqueous phases, by their wet removal, by the redistribution of the species by additional vertical transport in convective cells, and finally by modifying the photolysis rates. Unfortunately, the impact of clouds and their chemistry of these radicals can be hardly deduced from rare experimental data. Hence, adequate treatment of clouds and precipitation in atmospheric transport/chemistry models is needed. Its development raises some problems since cloud processes are largely a subgrid phenomena relative to the scales resolved in global models. Such models use scavenging coefficients (often proportional to the precipitation rate) or determined from empirical or microphysical considerations. Advanced models make more realistic calculations of the aqueous phase chemistry and wet removal, but assumed that clouds were monodisperse and all the droplets have the same composition. These models were developed to study acid deposition, and thus nonprecipitating clouds have often not been considered, despite the fact that most of clouds do not precipitate.

Atmospheric chemical models often use the Henry's law equilibrium [Schwartz, 1986; Seinfeld, 1986] to describe the

Copyright 1996 by the American Geophysical Union.

Paper number 96JD01548.

0148-0227/96/96JD-01548\$09.00 partitioning of a species between gas and aqueous phase (fog, cloud and rain) while several experimental studies [Noone et al., 1988; Collett et al., 1993; Pandis and Seinfeld, 1990; Pandis and Seinfeld, 1991; Winiwarter et al., 1992] have reported many deviations from this law. The most common explanation for these deviations from Henry's law for the bulk samples is the introduction of a bias in the sampling procedure [Pandis and Seinfeld, 1991]. On the basis of an analysis of chemical contents of tropical rains from convective clouds Cautenet and Lefeivre [1994], found that for $\mathrm{HNO}_{3}$, $\mathrm{NH}_{3}, \mathrm{HCOOH}$, the dilution coefficients are particularly weak, far less than the value expected by the effect of simple dilution. Moreover, they emphasized that in order to analyze the chemical composition of rain, it is necessary to classify rain events according to the granulometric type of the precipitating clouds systems (convective or stratiform). Therefore, the polydisperse feature of the cloud system is of primary importance in the analysis of the chemical content of the rain.

We expect that the aqueous and gaseous reactions and the partitioning of the liquid water content in two main different drop populations are also responsible for the deviations from Henry's law in the case of soluble species. Bulk samplings are usually of two main types. The most common corresponds to measurements obtained from a pluviometer. They are timeintegrated measurements. Other measurements are sometimes done in real clouds with airborne apparatus. We expect that measurements made on the edges of clouds may provide significantly different results from those obtained in the middle region of the clouds, in terms of dissolved-gases contents. This spatial feature is likely due to the differences of chemical composition of the interstitial air in the cloud with air surrounding it, and is an indirect effect of mixing and transport. Another source of spatial differences in the deviation from Henry's law is the polydisperse aspect of some clouds with, for example, two populations of drops of different sizes (cloud droplets and raindrops). Then, in many clouds we may observe a combination of these two effects as it will be demonstrated in our simulation for two highly soluble species 
$\mathrm{HCOOH}$, and $\mathrm{H}_{2} \mathrm{O}_{2}$ whose aqueous concentrations could be experimentally measured.

Depletion of tropospheric ozone in presence of clouds is still an open question. Most of the first studies concerning the effects of clouds on tropospheric ozone chemistry have predicted significant depletion of ozone induced by clouds in global situations [Lelieveld and Crutzen, 1990; Dentener, 1993] with alternation of clear and cloudy conditions. Nevertheless, over one cloud life cycle, small effects on $\mathrm{O}_{3}$ are expected, but noticeable changes in radical chemistry and subtraction of soluble species from gas phase already occur. Indirect effects of clouds such as perturbing the $[\mathrm{NO}] /\left[\mathrm{NO}_{2}\right]$ ratio as a consequence of radicals scavenging and modified photolysis rates are already significant within one isolated cloud simulation. During the cloud event, because of the inhibition of the conversion of $\mathrm{NO}$ into $\mathrm{NO}_{2}$, excess of $\mathrm{NO}$ exists relatively to clear conditions, and it will be consumed after the cloud dissipates. Obviously, a delay will occur depending whether the conversion of excess NO into $\mathrm{NO}_{2}$ after the cloud can be expected particularly if the radicals $\mathrm{RO}_{2}$ have been washed out. Such effects of an isolated cloud on this ratio have been found in our simulation.

As previously underlined, the variation of concentrations (in gas or aqueous phases) versus the droplet radius are often based on a strongly limiting hypothesis that the cloud is monodisperse. More studies are needed to look at the effect of a polydisperse cloud and can be obtained by integrating the results over a whole droplet spectrum.

In this study, we first show how the radical chemistry is affected by the presence of either a monodisperse cloud or a polydisperse cloud, and compare the results. (Metals and organic aerosols inside the drops are not included in our simulation because of their poorly known reactions with chemical species). We focus on the process of transfer between the gas and aqueous phases (fully coupled chemistries) and on the consequences on soluble species which it could induce with respect to the deviations from Henry's law.

We carried out a simulation with a chemical box model similar to Jacob [1986], but with specific species values of the accommodation coefficient $\alpha$, a liquid water content which varies in time, and two different drop sizes. This box model study constitutes the first part of our paper and would be taken as the reference case for the study of the monodisperse cloud effects. The polydisperse aspect of clouds is discussed in a second part in the framework of a dynamic model that simulates contrasting types of clouds (continental versus maritime). We examine the behavior of 12 chemical species involved in the ozone tropospheric chemistry in the presence of an orographic cloud. The selected scenario enables us to separate easily the microphysical processes along the mountain slope. The ozone chemistry is that of a non polluted atmosphere with a low amount of $\mathrm{NO}_{\mathbf{x}}$. In the box model, gaseous, aqueous reactions and mass transfer are taken into account as is done for the dynamic models of clouds. In both cases, the duration of simulation is 3 hours.

\section{Description of the Model}

\section{The Chemical Module}

This model treats 12 gaseous phase species with reactions derived from Lelieveld and Crutzen [1990]. The aqueous phase reactions are derived from the work of Lelieveld and Crutzen [1991]. Tables 1, 2 and 3 give, respectively, the gas phase reactions, the equilibrium reactions between the two phases, and the aqueous phase reactions. Photolysis rates are held constant during the whole simulation in order to focus exclusively on the sensitivity to drop size. The complete chemical scheme takes the following form:

$$
\begin{gathered}
\frac{d C_{g}}{d t}=P_{g}-D_{g} C_{g}-L k_{t}\left(C_{g}-\frac{C_{a q}}{L H_{e f f} R T}\right) \\
\frac{d C_{a q}}{d t}=P_{a q}-D_{a q} C_{a q}+L k_{t}\left(C_{g}-\frac{C_{a q}}{L H_{e f f} R T}\right)
\end{gathered}
$$

where $C_{g}$ and $C_{a q}$ are, respectively, the gaseous and the aqueous water concentrations, expressed in molecules per cubic centimeter of air. $P_{g}, P_{a q} D_{g}$, and $D_{a q}$ are the production and destruction rates, respectively, for gaseous and aqueous phases. In the case of dissociating species, $C_{a q}$ is the sum of the dissolved species and dissociated parts of the aqueous concentration. $H_{\text {eff }}$ is the effective Henry's law constant (in mole per liter per atmosphere) which includes the possible dissociation of the chemical species in the aqueous phase as a function of the $p H . L$ is the liquid water content $(v / v) ; k_{t}$ is the mass transfer coefficient [Schwartz, 1986] to liquid water. The latter strongly depends on the drop radius $r$ and the accommodation coefficient $\alpha$, as can be seen in the following formula [Schwartz , 1986]:

$$
k_{t}=\left(\frac{r^{2}}{3 D_{g}}+\frac{4 r}{3 \alpha \bar{v}}\right)^{-I}
$$

Although the accommodation coefficient varies from one species to another (see Table 5), we verified that for soluble species the consequence on the values of $k_{t}$ induced by this variation is negligible in comparison with those related to the drop radius.

An exponential method [Chang et al., 1987] has been chosen for the solver of these two equations because of its efficiency [see Gregoire et al., 1994]. Mixing of drops of different $p \mathbf{H}$ is one of the major sources of deviations to Henry's law [Pandis and Seinfeld, 1991]. We held pH constant (4.16) in order to focus on the sensitivity to varying the other parameters.

\section{Initial Conditions}

Initial gaseous concentrations, typically of low levels of $\mathrm{NO}_{\mathrm{x}}$, are given in Table 4. The initial spatial gaseous distribution (in molecules per cubic centimeter) of species is taken to be constant with height due to the lack of experimental vertical profiles of the chemical species in case of low levels of $\mathrm{NO}_{x}$. However, this provides the advantage of simplifying the analysis and the interpretation of the results.

In the box model, the liquid water content varies with time as indicated on Figure 1. Two cases have been simulated, one corresponding to an aqueous phase with a constant mean diameter of 20 microns, the other one with a diameter of 200 microns. The liquid water content and chemical intialization are taken as identical, as in the two cloud cases. 
Table 1. List of the Reactions and Equilibrium in the Gas Phase With Corresponding Rate and Equilibrium Constants [from Lelieveld and Crutzen, 1991].

\begin{tabular}{|c|c|c|}
\hline & Gas Phase Reaction Scheme $^{2}$ & Rate constants ${ }^{\circ}$ \\
\hline$G 1^{c}$ & $\mathrm{O}_{3}+\mathrm{H}_{2} \mathrm{O}+\mathrm{hv} \rightarrow 2 \mathrm{OH}+\mathrm{O}_{2}$ & $J_{\text {eff }}$ \\
\hline G2 & $\mathrm{O}_{3}+\mathrm{OH} \rightarrow \mathrm{HO}_{2}+\mathrm{O}_{2}$ & $1.6 \times 10^{-12} \exp (-940 / \mathrm{T})$ \\
\hline G3 & $\mathrm{O}_{3}+\mathrm{HO}_{2} \cdot \rightarrow \mathrm{OH}^{\cdot}+2 \mathrm{O}_{2}$ & $1.1 \times 10^{-14} \exp (-500 / \mathrm{T})$ \\
\hline G4 & $2 \mathrm{HO}_{2} \rightarrow \mathrm{H}_{2} \mathrm{O}_{2}+\mathrm{O}_{2}$ & $\begin{array}{l}\left(2.3 \times 10^{-.13} \exp (600 / \mathrm{T})+1.7 \times 10^{-34}[\mathrm{M}] \exp (1000 / \mathrm{T})\right) \\
\times\left(1+1.4 \times 10^{-21}\left[\mathrm{H}_{2} \mathrm{O}\right] \exp (2200 / \mathrm{T})\right)\end{array}$ \\
\hline G5 & $\mathrm{H}_{2} \mathrm{O}_{2}+\mathrm{hv} \rightarrow 2 \mathrm{OH}$ & $4.6 \times 10^{-0}$ \\
\hline G6 & $\mathrm{H}_{2} \mathrm{O}_{2}+\mathrm{OH}^{-} \rightarrow \mathrm{HO}_{2}+\mathrm{H}_{2} \mathrm{O}$ & $3.3 \times 10^{-12} \exp (-200 / T)$ \\
\hline G7 & $\mathrm{CH}_{4}+\mathrm{OH} \cdot+\mathrm{O}_{2}+\mathrm{M} \rightarrow \mathrm{CH}_{3} \mathrm{O}_{2} \cdot+\mathrm{H}_{2} \mathrm{O}+\mathrm{M}$ & $2.3 \times 10^{-12} \exp (-1700 / T)$ \\
\hline G8 & $\mathrm{CH}_{3} \mathrm{O}_{2}+\mathrm{HO}_{2} \cdot \rightarrow \mathrm{CH}_{3} \mathrm{O}_{2} \mathrm{H}+\mathrm{O}_{2}$ & $4.0 \times 10^{-12}$ \\
\hline G9 & $\mathrm{CH}_{3} \mathrm{O}_{2} \mathrm{H}+\mathrm{O}_{2}+\mathrm{hv} \rightarrow \mathrm{CH}_{2} \mathrm{O}+\mathrm{HO}_{2}+\mathrm{OH}^{\cdot}$ & $4.6 \times 10^{-6}$ \\
\hline G10 & $\mathrm{CH}_{3} \mathrm{O}_{2} \mathrm{H}+\mathrm{OH} \rightarrow \mathrm{CH}_{3} \mathrm{O}_{2} \cdot+\mathrm{H}_{2} \mathrm{O}$ & $5.6 \times 10^{-12}$ \\
\hline Gl1 & $\mathrm{CH}_{3} \mathrm{O}_{2} \mathrm{H}+\mathrm{OH} \rightarrow \mathrm{CH}_{2} \mathrm{O}+\mathrm{OH}+\mathrm{H}_{2} \mathrm{O}$ & $4.4 \times 10^{-12}$ \\
\hline G12 & $\mathrm{CH}_{2} \mathrm{O}+2 \mathrm{O}_{2}+\mathrm{hv} \rightarrow \mathrm{CO}+2 \mathrm{HO}_{2}$ & $1.7 \times 10^{-3}$ \\
\hline G13 & $\mathrm{CH}_{2} \mathrm{O}+\mathrm{hv} \rightarrow \mathrm{CO}+\mathrm{H}_{2}$ & $3.3 \times 10^{-3}$ \\
\hline G14 & $\mathrm{CH}_{2} \mathrm{O}+\mathrm{OH}+\mathrm{O}_{2} \rightarrow \mathrm{CO}+\mathrm{HO}_{2}+\mathrm{H}_{2} \mathrm{O}$ & $1.1 \times 10^{-11}$ \\
\hline G15 & $\mathrm{CO}+\mathrm{OH} \cdot+\mathrm{O}_{2}+\mathrm{M} \rightarrow \mathrm{CO}_{2}+\mathrm{HO}_{2} \cdot+\mathrm{M}$ & $2.4 \times 10^{-1 s}$ \\
\hline G16 & $\mathrm{NO}+\mathrm{O}_{3} \rightarrow \mathrm{NO}_{2}+\mathrm{O}_{2}$ & $2.0 \times 10^{-12} \exp (-1400 / \mathrm{T})$ \\
\hline G17 & $\mathrm{NO}_{2}+\mathrm{O}_{2}+\mathrm{hv} \rightarrow \mathrm{NO}+\mathrm{O}_{3}$ & $5.6 \times 10^{-3}$ \\
\hline G18 & $\mathrm{NO}+\mathrm{HO}_{2} \cdot \rightarrow \mathrm{NO}_{2}+\mathrm{OH}$ & $3.7 \times 10^{-12} \exp (240 / \mathrm{T})$ \\
\hline G19 & $\mathrm{NO}+\mathrm{CH}_{3} \mathrm{O}_{2}+\mathrm{O}_{2} \rightarrow \mathrm{NO}_{2}+\mathrm{CH}_{2} \mathrm{O}+\mathrm{HO}_{2}-$ & $4.2 \times 10^{-12} \exp (180 / \mathrm{T})$ \\
\hline G20 & $\mathrm{NO}_{2}+\mathrm{OH}(+\mathrm{M}) \rightarrow \mathrm{HNO}_{3}(+\mathrm{M})$ & $1.2 \times 10^{-11}$ \\
\hline G21 & $\mathrm{HNO}_{3}+\mathrm{hv} \rightarrow \mathrm{NO}_{2}+\mathrm{OH}$ & $3.2 \times 10^{-1}$ \\
\hline E22 & $\mathrm{CH}_{2} \mathrm{O}+\mathrm{HO}_{2} \cdot \leftrightarrow \mathrm{O}_{2} \mathrm{CH}_{2} \mathrm{OH}$ & $6.7 \times 10^{-15}$ \\
\hline G23 & $\mathrm{O}_{2} \mathrm{CH}_{2} \mathrm{OH}+\mathrm{HO}_{2} \cdot \rightarrow \mathrm{HCO}_{2} \mathrm{H}+\mathrm{HO}_{2} \cdot+\mathrm{O}_{2}$ & $2.0 \times 10^{-12}$ \\
\hline $\mathrm{G} 24$ & $\mathrm{O}_{2} \mathrm{CH}_{2} \mathrm{OH}+\mathrm{NO}+\mathrm{O}_{2} \rightarrow \mathrm{HCO}_{2} \mathrm{H}+\mathrm{HO}_{2}+\mathrm{NO}_{2}$ & $7.0 \times 10^{-12}$ \\
\hline G25 & $\begin{array}{l}\mathrm{O}_{2} \mathrm{CH}, \mathrm{OH}+\mathrm{O}_{2} \mathrm{CH}_{2} \mathrm{OH} \rightarrow 2 \mathrm{HCO}_{2} \mathrm{H}+\mathrm{HO}_{2} \cdot+ \\
\mathrm{H}_{2} \mathrm{O}\end{array}$ & $1.2 \times 10^{-15}$ \\
\hline G26 & $\mathrm{HCO}_{2} \mathrm{H}+\mathrm{OH}+\mathrm{O}_{2} \rightarrow \mathrm{CO}_{2}+\mathrm{HO}_{2}+\mathrm{H}_{2} \mathrm{O}$ & $3.2 \times 10^{-15}$ \\
\hline
\end{tabular}

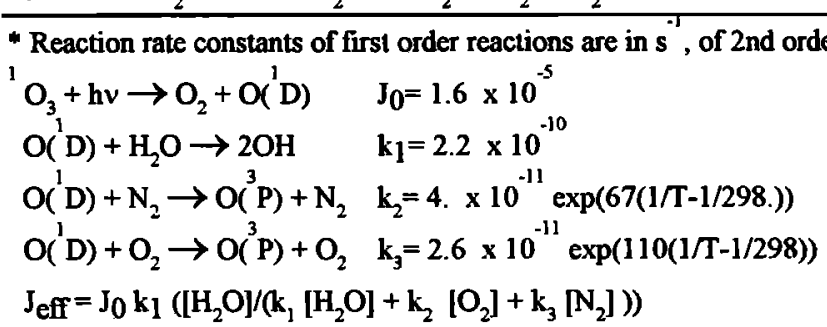

\section{Mesoscale Simulation}

A complete description of the mountain wave scenario used to create the orographic cloud can be found in previous papers [Chaumerliac et al., 1987, Chaumerliac et al., 1990]. The half width of the mountain is $25 \mathrm{~km}$ and its height is $1 \mathrm{~km}$. The initial wind is horizontal and homogeneous with a velocity of $20 \mathrm{~m} / \mathrm{s}$, and the initial relative humidity is assumed to be $80 \%$ below $3 \mathrm{~km}$. The mesoscale model [Nickerson et $a l ., 1986]$ covers an horizontal domain of $300 \mathrm{~km}$ over land with a grid spacing of $10 \mathrm{~km}$. The time step is $10 \mathrm{~s}$ and there are 16 computational levels in the vertical terrain-following coordinate system (v). The dynamical, microphysical, and chemical processes are fully interactive in the model. The simulation lasts for 3 hours and is two-dimensional.

\section{Microphysical Scheme}

The microphysical parameterization uses the BerryReinhardt [1974] scheme. This scheme appears to be a good compromise to fulfill the requirements of both the accuracy of description of the drop-size distribution of rain, and the reductions in computational costs [Huret et al., 1994]. Particularly, as a quasi-spectral scheme it gives a more realistic description of the evaporation process than the wellknown scheme of Kessler [1969]. Differences between the two 
Table 2. List of the Gas-Aqueous Phase Equilibria With Corresponding Henry's Law Constants and of Aqueous Equilibria With Corresponding DissociationConstants [from Lelieveld and Crutzen, 1991].

\begin{tabular}{|c|c|c|}
\hline & Gas-Aqueous and Aqueous Phase Equilibria & Henry's Law and Dissociation Constants $\mathrm{K}_{298}^{*}$ \\
\hline E1 & $\mathrm{H}_{2} \mathrm{O} \leftrightarrow \mathrm{H}^{+}+\mathrm{OH}^{-}$ & $1.0 \times 10^{-14} \exp (-6716(1 / \mathrm{T}-1 / 298))$ \\
\hline H1 & $\mathrm{O}_{3}$ (gas) $\leftrightarrow \mathrm{O}_{3}$ (aq) & $1.1 \times 10^{-2} \exp (2300(1 / \mathrm{T}-1 / 298))$ \\
\hline $\mathrm{H} 2$ & $\mathrm{H}_{2} \mathrm{O}_{2}$ (gas) $\leftrightarrow \mathrm{H}_{2} \mathrm{O}_{2}$ (aq) & $7.4 \times 10^{4} \exp (6615(1 / T-1 / 298))$ \\
\hline E2 & $\mathrm{H}_{2} \mathrm{O}_{2}(\mathrm{aq}) \leftrightarrow \mathrm{HO}_{2}^{-}+\mathrm{H}^{+}$ & $2.2 \times 10^{-12} \exp (-3730(1 / T-1 / 298))$ \\
\hline $\mathrm{H3}$ & $\mathrm{CH}_{3} \mathrm{O}_{2} \mathrm{H}$ (gas) $\leftrightarrow \mathrm{CH}_{3} \mathrm{O}_{2} \mathrm{H}(\mathrm{aq})$ & $2.2 \times 10^{2} \exp (5653(1 / \mathrm{T}-1 / 298))$ \\
\hline H4 & $\mathrm{CH}_{2} \mathrm{O}$ (gas) $\leftrightarrow \mathrm{CH}_{2}(\mathrm{OH})_{2}(\mathrm{aq})$ & $6.3 \times 10^{3} \exp (6425(1 / \mathrm{T}-1 / 298))$ \\
\hline H5 & $\mathrm{HNO}_{3}$ (gas) $\leftrightarrow \mathrm{HNO}_{3}$ (aq) & $2.1 \times 10^{3} \exp (8700(1 / \mathrm{T}-1 / 298))$ \\
\hline E3 & $\mathrm{HNO}_{3}(\mathrm{aq}) \leftrightarrow \mathrm{H}^{+}+\mathrm{NO}_{3}^{-}$ & 15.4 \\
\hline H6 & $\mathrm{HO}_{2} \cdot$ (gas) $\leftrightarrow \mathrm{HO}_{2} \cdot$ (aq) & $2.0 \times 10^{3} \exp (6600(1 / \mathrm{T}-1 / 298))$ \\
\hline E4 & $\mathrm{HO}_{2} \cdot(\mathrm{aq}) \leftrightarrow \mathrm{H}^{+}+\mathrm{O}_{2}^{-}(\mathrm{aq})$ & $3.5 \times 10^{-3}$ \\
\hline H7 & $\mathrm{OH} \cdot(\mathrm{gas}) \leftrightarrow \mathrm{OH} \cdot(\mathrm{aq})$ & $9.0 \times 10^{5}$ \\
\hline H8 & $\mathrm{NO}_{2}$ (gas) $\leftrightarrow \mathrm{NO}_{2}$ (aq) & $6.4 \times 10^{-5} \exp (2500(1 / \mathrm{T}-1 / 298))$ \\
\hline H9 & NO (gas) $\leftrightarrow$ NO (aq) & $1.9 \times 10^{-3} \exp (1480(1 / \mathrm{T}-1 / 298))$ \\
\hline H10 & $\mathrm{CH}_{3} \mathrm{O}_{2} \cdot$ (gas) $\leftrightarrow \mathrm{CH}_{3} \mathrm{O}_{2} \cdot$ (aq) & $2.0 \times 10^{3} \exp (6600(1 / \mathrm{T}-1 / 298))$ \\
\hline H11 & $\mathrm{HCO}_{2} \mathrm{H}$ (gas) $\leftrightarrow \mathrm{HCO}_{2} \mathrm{H}(\mathrm{aq})$ & $3.7 \times 10^{3} \exp (5700(1 / T-1 / 298))$ \\
\hline E5 & $\mathrm{HCO}_{2} \mathrm{H}(\mathrm{aq}) \leftrightarrow \mathrm{H}^{+}+\mathrm{HCO}_{2}^{-}$ & $1.8 \times 10^{-4} \exp (-1510(1 / T-1 / 298))$ \\
\hline
\end{tabular}

* Henry's law constants in mol $\times \mathrm{l}^{-1} \mathrm{~atm}^{-1}$ and dissociation constants in mol $\times 1^{-1}$ at $298 \mathrm{~K}$.

schemes are detailed in the appendix. Moreover, for the parameterization of the microphysical processes, the BerryReinhardt scheme allows for better accuracy by taking into account more detailed features of the cloud. Cloud water can be converted into rainwater even for small values of its mixing ratio. For example, the autoconversion rate depends on the type of air mass and on the cloud water mixing ratio. This dependence is represented by a coefficient named $a_{2}$ which expression is directly linked to the total number of cloud droplets $N_{c w}$ and their standard deviation $\sigma_{c}$. This coefficient is particularly important because it takes into account the nature of the air mass and enables parameterizations for more or less precipitating clouds: The higher the value of $a_{2}$ the more precipitating the cloud is.

Two runs are driven with different types of orographic clouds. They differ in the type of air mass which is considered. A continental air mass gives rise to a cloud with small drops (hereafter named continental cloud), while the maritime orographic cloud corresponds to an maritime air mass. The maritime cloud has two populations of drops: droplets of cloud water and big drops of rainwater. The total liquid water contents of these two clouds are identical, only the partitioning

Table 3. List of the Reactions in the Aqueous Phase With Corresponding Rate Constants [from Lelieveld and Crutzen, 1991].

\begin{tabular}{|c|c|c|}
\hline & Aqueous Phase Reaction Scheme & Rate Constants at $298 \mathrm{~K}^{*}$ \\
\hline $\mathrm{Al}$ & $\mathrm{H}_{2} \mathrm{O}_{2}+\mathrm{hv} \rightarrow 2 \mathrm{OH}$ & G5 $\times 1.6\left(\right.$ in s $\left.^{-1}\right)$ \\
\hline A2 & $\mathrm{O}_{3}+\mathrm{h} v \rightarrow \mathrm{H}_{2} \mathrm{O}_{2}+\mathrm{O}_{2}$ & G1 $\times 1.6\left(\right.$ in s $\left.^{-1}\right)$ \\
\hline A3 & $\mathrm{CH}_{2}(\mathrm{OH})_{2}+\mathrm{OH}^{\cdot}+\mathrm{O}_{2} \rightarrow \mathrm{HCO}_{2} \mathrm{H}+\mathrm{HO}_{2} \cdot+\mathrm{H}_{2} \mathrm{O}$ & $2.0 \times 10^{y} \exp (-1500(1 / \mathrm{T}-1 / 298))$ \\
\hline A4 & $\mathrm{HCO}_{2} \mathrm{H}+\mathrm{OH}+\mathrm{O}_{2} \rightarrow \mathrm{CO}_{2}+\mathrm{HO}_{2}+\mathrm{H}_{2} \mathrm{O}$ & $1.6 \times 10^{8} \exp (-1500(1 / \mathrm{T}-1 / 298))$ \\
\hline A5 & $\mathrm{HCO}_{2}^{-}+\mathrm{OH}^{-}+\mathrm{O}_{2} \rightarrow \mathrm{CO}_{2}+\mathrm{HO}_{2}^{-}+\mathrm{OH}^{-}$ & $2.5 \times 10^{y} \exp (-1500(1 / \mathrm{T}-1 / 298))$ \\
\hline A6 & $\mathrm{O}_{3}+\mathrm{O}_{2}^{-} \stackrel{\mathrm{H}^{2} \mathrm{O}}{>}>\mathrm{OH}+\mathrm{OH}^{-}+2 \mathrm{O}_{2}$ & $1.5 \times 10^{9} \exp (-1500(1 / \mathrm{T}-1 / 298))$ \\
\hline A7 & $\mathrm{HO}_{2}+\mathrm{O}_{2}^{-}+\mathrm{H}_{2} \mathrm{O} \rightarrow \mathrm{H}_{2} \mathrm{O}_{2}+\mathrm{OH}^{-}+\mathrm{O}_{2}$ & $1.0 \times 10^{8} \exp (-1500(1 / T-1 / 298))$ \\
\hline A8 & $\mathrm{H}_{2} \mathrm{O}_{2}+\mathrm{OH}^{\cdot} \rightarrow \mathrm{HO}_{2}+\mathrm{H}_{2} \mathrm{O}$ & $2.7 \times 10 \exp (-1715(1 / \mathrm{T}-1 / 298))$ \\
\hline A9 & $\mathrm{CH}_{3} \mathrm{O}_{2}+\mathrm{O}_{2}^{-}+\mathrm{H}_{2} \mathrm{O} \rightarrow \mathrm{CH}_{3} \mathrm{O}_{2} \mathrm{H}+\mathrm{OH}^{-}+\mathrm{O}_{2}$ & $5.0 \times 10 \exp (-1610(1 / \mathrm{T}-1 / 298))$ \\
\hline A10 & $\mathrm{CH}_{3} \mathrm{O}_{2} \mathrm{H}+\mathrm{OH}^{\cdot} \rightarrow \mathrm{CH}_{3} \mathrm{O}_{2} \cdot+\mathrm{H}_{2} \mathrm{O}$ & $2.7 \times 10^{\prime} \exp (-1715(1 / \mathrm{T}-1 / 298))$ \\
\hline Al1 & $\mathrm{CH}_{3} \mathrm{O}_{2} \mathrm{H}+\mathrm{OH} \cdot \rightarrow \mathrm{CH}_{2}(\mathrm{OH})_{2}+\mathrm{OH}^{\cdot}$ & $1.9 \times 10^{\prime} \exp (-1860(1 / \mathrm{T}-1 / 298))$ \\
\hline
\end{tabular}

* Rate constants are in $\mathrm{mol}^{-1} \mathrm{~s}$ (except for $\mathrm{Al}$ and $\mathrm{A} 2$ ). 
Table 4: Initial Values of the 12 Species

\begin{tabular}{llllllllllll}
\hline $\mathrm{O}_{3}$ & $\mathrm{H}_{2} \mathrm{O}_{2}$ & $\mathrm{CH}_{3} \mathrm{O}_{2} \mathrm{H}$ & $\mathrm{CH}_{2} \mathrm{O}$ & $\mathrm{CO}$ & $\mathrm{HNO}_{3}$ & $\mathrm{HO}_{2}$ & $\mathrm{OH}$ & $\mathrm{NO}_{2}$ & $\mathrm{NO}$ & $\mathrm{CH}_{3} \mathrm{O}_{2}$ & $\mathrm{HCOOH}$ \\
$30 \mathrm{ppb}$ & $2 \mathrm{ppb}$ & $0 \mathrm{ppb}$ & $\mathbf{0} \mathrm{ppb}$ & $100 \mathrm{ppb}$ & $100 \mathrm{ppt}$ & $0 \mathrm{ppt}$ & $0 \mathrm{ppt}$ & $5 \mathrm{ppt}$ & $5 \mathrm{ppt}$ & $0 \mathbf{p p t}$ & $0 \mathrm{ppt}$ \\
\hline
\end{tabular}

specified by the primary autoconversion process of cloud into rain is different. This provided us an idealized situation for cloud chemistry study.

Continental cloud. Its spectrum is characterized by a value of $\sigma_{c}$ equal to 0.16 and a mean diameter of $20 \mu \mathrm{m}$. The orographic cloud has a maximum $q_{c w}$ value of $0.73 \mathrm{~g} \mathrm{~kg}^{-1}$, but it is almost nonprecipitating $\left(0.0012 \mathrm{~g} \mathrm{~kg}^{-1}\right.$ for the maximum rainwater mixing ratio, see Figures $2 \mathrm{a}, 2 \mathrm{~b}$ ). This leads to a value of $a_{2}=0.17$.

Maritime cloud. For this case, the value of $a_{2}$ is 0.28 , so this cloud reaches higher values of rainwater mixing ratio (maximum value equal to $0.28 \mathrm{~g} \mathrm{~kg}^{-1}$ ). However, it has a lower maximum value of the cloud mixing ratio of $0.3 \mathrm{~g} \mathrm{~kg}^{-1}$ than the continental cloud (see Figures $2 c, 2 d$ ). The spatial evolution of the raindrops diameter is shown in Figure 3.

After 3 hours of simulation, the main characteristics are as follows: A large longitudinal extent and a high maximum value for continental cloud water with low rain content, whereas the maritime cloud shows lower cloud water contents and higher values of rain content.

The complete chemical scheme is for the case of polydisperse clouds:

$$
\begin{aligned}
\frac{d C_{g}}{d t}= & P_{g}-D_{g} C_{g}-x w c k_{t}\left(C_{g}-\frac{C_{c l}}{x w c H_{e f f} R T}\right) \\
& -x w r k_{t_{r}}\left(C_{g}-\frac{C_{r}}{x w r H_{e f f} R T}\right) \\
\frac{d C_{c l}}{d t}= & P_{c l}-D_{c l} C_{c l}+x w c k_{t}\left(C_{g}-\frac{C_{c l}}{x w c H_{e f f} R T}\right) \\
\frac{d C r}{d t}= & P_{r}-D_{r} C r+x w c k_{t}\left(C_{g}-\frac{C_{r}}{x w c H_{e f f} R T}\right)
\end{aligned}
$$

where $C_{g}$ and $C_{c l}, C_{r}$ are, respectively, the gaseous, cloud water, and rainwater concentrations, expressed in molecules per cubic centimeter of air. $P_{g}, P_{c l}, P_{r}, D_{g}, D_{c l}, D_{r}$ are the product and destruction rates, respectively, for gaseous and aqueous phases. Here $x w c$ and $x w r$ are the cloud water content and rainwater content $(v / v) ; k_{t}$ and $k_{t r}$ are the mass transfer coefficient [Schwartz, 1986] to cloud water and rainwater, respectively. Coupling the chemical module with dynamical and microphysical models has been realized by using timesplitting. A quasi-steady state approximation has been adopted but the transfer is resolved separately of the chemical variations. The chemical module has a time step which has been fit to our scenario: it is the twentieth of the time step used for the dynamical and microphysical processes. This choice ensures the conservation of chemical species during the simulation.

\section{Results}

\section{Chemical Box Model}

The liquid water content (Figure 1 ) is equal to zero during the first $15 \mathrm{~min}$. Some initial chemical concentrations are equal to zero ; there is a chemical adjustment during the first minutes leading to an increase in concentrations for most of the species. During this chemical adjustment, ozone slightly decreases. For the remaining duration of simulation, most species show a net sensitivity to the fluctuations of liquid water content and not only to its bulk behavior. It is noteworthy that this sensitivity is higher in the case of small drops.

Since the two simulations differ only with respect to the drop size, the box model results highlight the sensitivity to this parameter. The effect of various solubilities can be seen. However, the classification of the species according to their sensitivity to drop size does not necessarily match the classification made according their solubility which is, in a decreasing order : $\mathrm{HNO}_{3}, \mathrm{HCOOH}, \mathrm{H}_{2} \mathrm{O}_{2}, \mathrm{CH}_{2} \mathrm{O}$, radicals $\mathrm{HO}_{2}$, and $\mathrm{CH}_{3} \mathrm{O}_{2}, \mathrm{OH}, \mathrm{CH}_{3} \mathrm{O}_{2} \mathrm{H}, \mathrm{NO}_{x}$ and ozone. Moderately or low soluble species will be found to have strong sensitivities to the drop diameter.

Ozone and $\mathrm{CH}_{3} \mathrm{O}_{2} \mathrm{H}$ (Figure 4a) are almost unaffected while the radicals $\mathrm{CH}_{3} \mathrm{O}_{2}$ (Figure 4b) and $\mathrm{HO}_{2}$ (not shown) show a net sensitivity to the drop diameter as $\mathrm{CH}_{2} \mathrm{O}, \mathrm{OH}$, and HCOOH do (Figure 4b, 4c). Gaseous concentrations of all these species are higher in the case of large diameters except for NO gas concentrations (Figure 4d) which are weaker in this case. The $\mathrm{RO}_{2}$ radicals $\mathrm{HO}_{2}$ and $\mathrm{CH}_{3} \mathrm{O}_{2}$ are 5 times higher, whereas $\mathrm{OH}$ is just 1.3 times higher in this last case. $\mathrm{NO}$ and $\mathrm{NO}_{2}$ are affected differently: NO concentrations decrease by a factor of 1.4 , while $\mathrm{NO}_{2}$ concentrations increase by a factor of 1.1 , leading to a $57 \%$ decrease in the $[\mathrm{NO}] /\left[\mathrm{NO}_{2}\right]$ ratio. These different behaviors of $\mathrm{NO}$ and $\mathrm{NO}_{2}$ are likely due to the gaseous chemical reactions G18 and G19 (Table 1). The G19 reaction produces formaldehyde, and

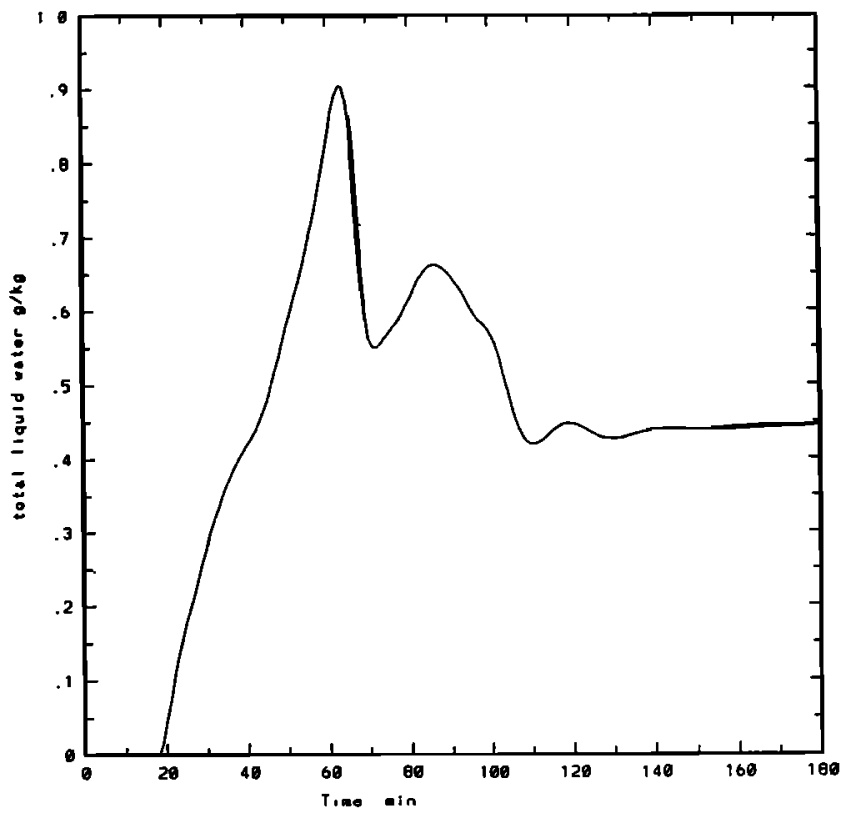

Figure 1. Box model: variation with time of the liquid water content. 

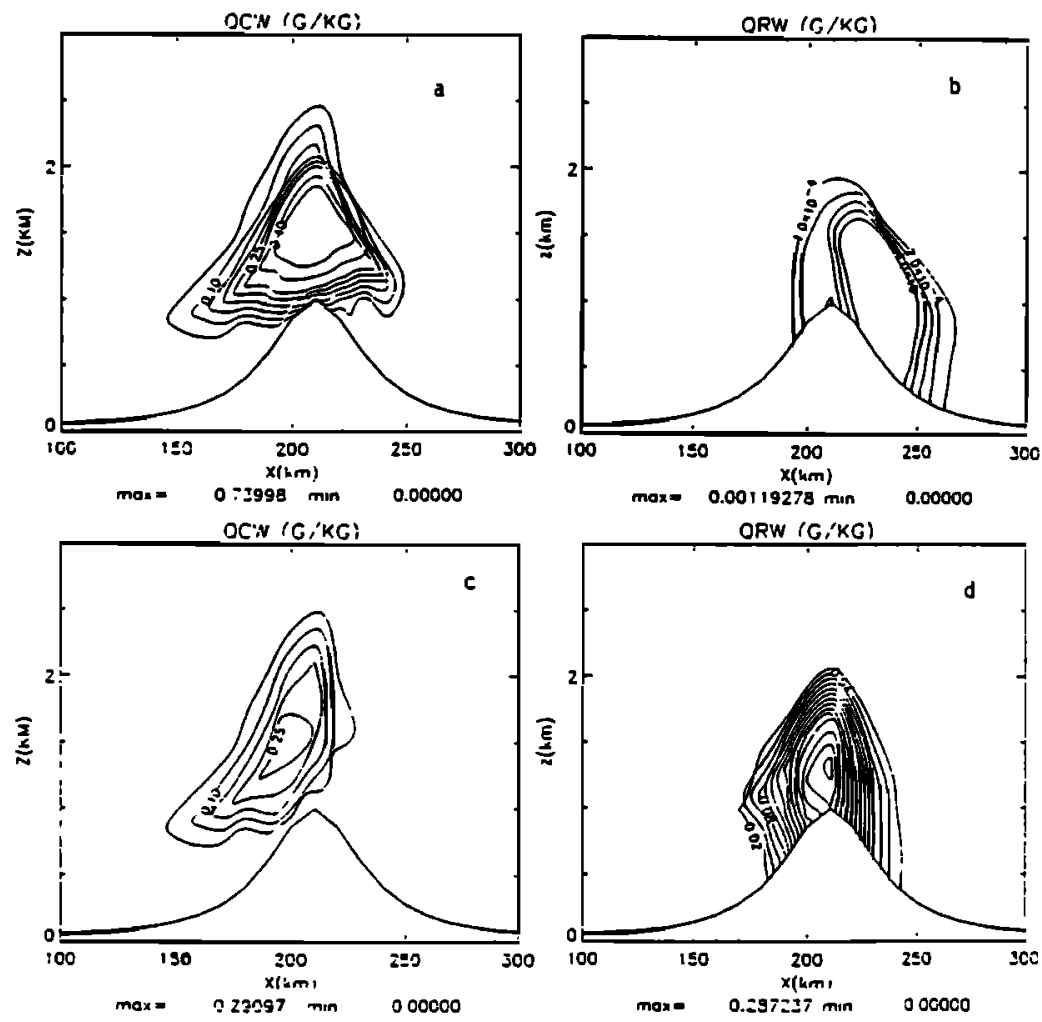

Figure 2. Mountain wave simulation; (a,c) cloud water content $q_{w}(g / k g)$ and (b,d) rainwater $q_{r^{2}}(g / k g)$; (a,b) continental cloud, (c,d) maritime cloud (time=3hours).

hence, in the large-drop case, concentrations of formaldehyde in the gas phase are higher. The $\left[\mathrm{NO} / / \mathrm{NO}_{2}\right]$ ratio characterizes the conversion of $\mathrm{NO}$ into $\mathrm{NO}_{2}$ which is of particular importance since the latter leads to formation of nitric acid and governs the production of ozone.

One can notice that there is a time delay in the response of all the scavenged species in the case of big drops in comparison with the small-drop run (note the shift in time of the maxima for instance). This is a noticeable effect of the

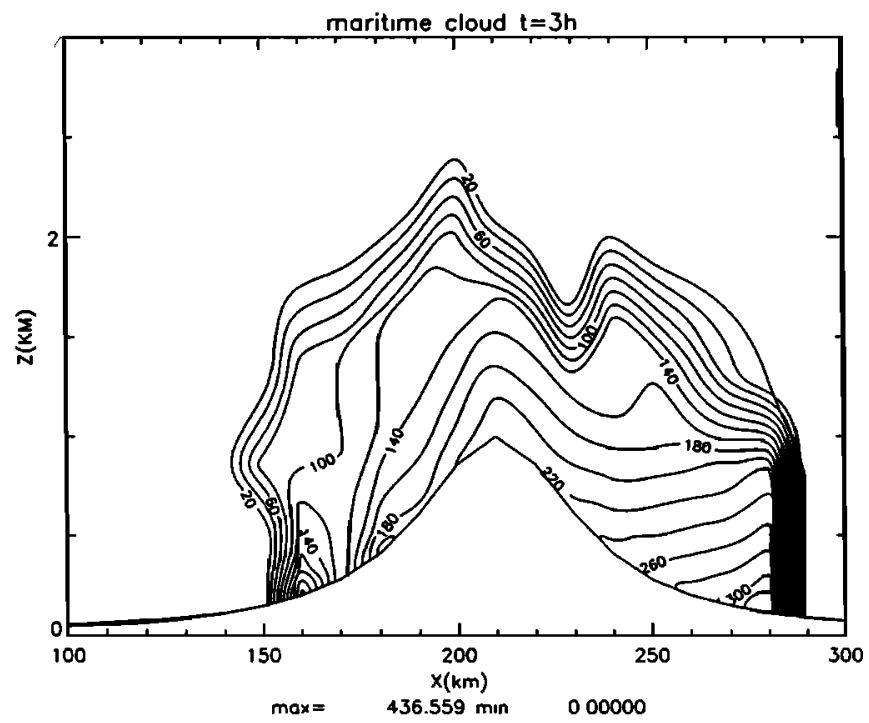

Figure 3. Mountain wave simulation, maritime cloud raindrop diameter. droplet size which can be explained by a longer time for a bigger drop to reach equilibrium with its gaseous environment.

Although $\mathrm{HO}_{2}, \mathrm{CH}_{3} \mathrm{O}_{2}$, and $\mathrm{OH}$ are moderately soluble species, they seem to be sensitive to the drop diameter. In order to understand the different behavior described above, let us recall that the gas to aqueous phase transfer is defined through the rate $L k_{t}$. This term explicitly depends on the liquid water content, the drop diameter, and the accommodation coefficient. The latter does not describe the solubility of the species, but the probability for a transition to occur from gas phase to aqueous phase and vice-versa. Hence, a small value of $\alpha$ means a slow equilibration as emphasized by Sander et al. [1995]. Also, $\alpha$ is the same, (at least the same order of magnitude) for species of highly different solubilities : $\mathrm{CH}_{3} \mathrm{O}_{2}, \mathrm{CH}_{2} \mathrm{O}, \mathrm{OH}, \mathrm{CH}_{3} \mathrm{O}_{2} \mathrm{H}, \mathrm{HCOOH}$ (see Table 5). $L k_{t}$ is smaller in the case of large drops and proportional to the accommodation coefficient.

The box model has thus proven to be useful in understanding the role of drop size in chemical processes. However, the sensitivity is likely enhanced because the cloud water is treated as monodisperse. In a real cloud, on the other hand, only a fraction of liquid water is converted into large drops. Moreover, this is done progressively. Large drops come from cloud water drops which already contain chemical species. This difference can be of primary importance since it leads to a completely different equilibration between the two phases. Finally, precipitation efficiently removes the species, while in the box model, a decrease of liquid water content allows a complete release of the chemical species into the gas phase. Since more formaldehyde is produced in gas phase in the large-drop case, more $\mathrm{CH}_{2} \mathrm{O}$ is transferred in aqueous 

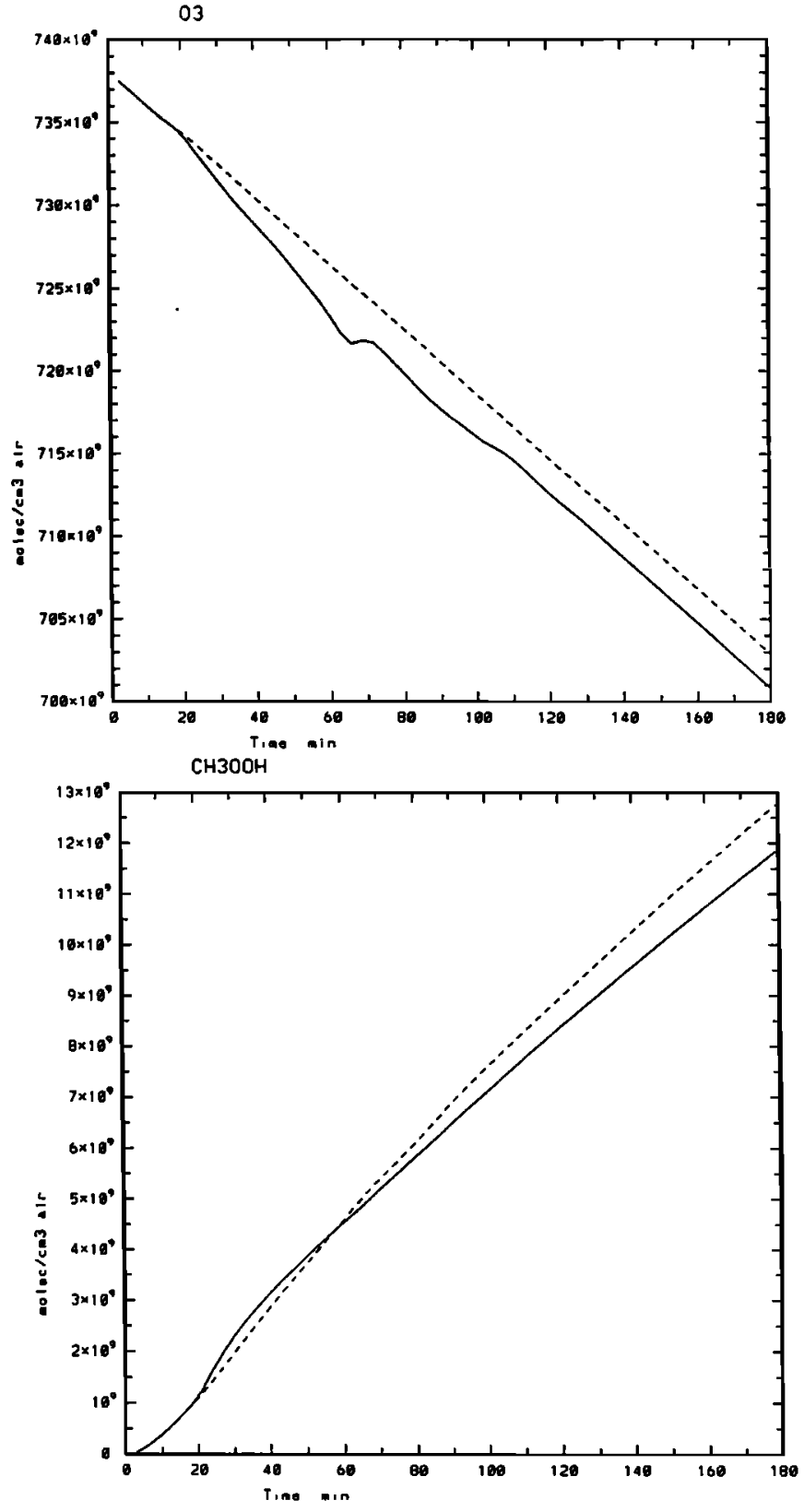
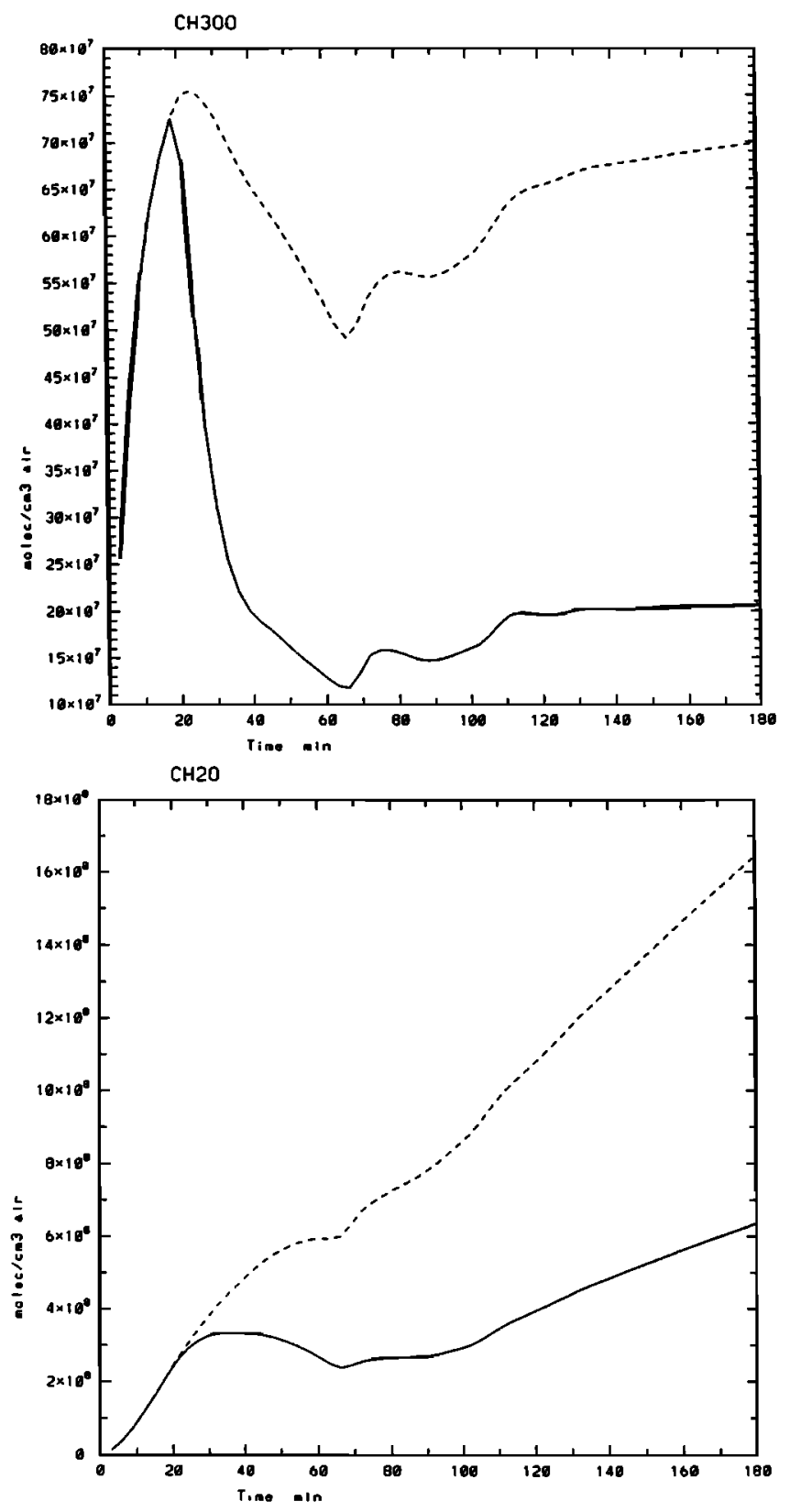

Figure 4. Results of box model rums (a) Ozone and $\mathrm{CH}_{3} \mathrm{O}_{2} \mathrm{H}$ gas concentrations (at the end of run of 3hours); (b) $\mathrm{CH}_{3} \mathrm{O}_{2}$ and $\mathrm{CH}_{2} \mathrm{O}$ gas concentrations; (c) $\mathrm{OH}$ and $\mathrm{HCOOH}$ gas concentrations; and (d) $\mathrm{NO}$ and $\mathrm{NO}_{2}$ gas concentrations; (solid line) 20 microns, (dotted line) 200 microns.

phase, leading to a higher production of formic acid in the present acidity conditions $(p \mathrm{H}<5)$. It is only during the decrease of the liquid water content that $\mathrm{HCOOH}$ gas concentrations are higher ( $>4000 \mathrm{~s})$.

\section{Mountain Wave Simulation: Gaseous Concentrations}

Continental case. The continental cloud is monodisperse. Hence, the main differences from the box model are the additional effects of transport along the mountain slope, and of evaporation, which essentially occurs on the downwind side. Obviously, we find again some general features of the box model.
Ozone is almost unchanged by the presence of the cloud as indicated by the slight deformation of the isolines (Figure 5a) around the top of the mountain. $\mathrm{H}_{2} \mathrm{O}_{2}$ is rapidly depleted after entering the cloud. With an initial value of $2 \mathrm{ppb}$, up to $80 \%$ is scavenged in the middle region of the cloud. The other species $\mathrm{CH}_{3} \mathrm{O}_{2} \mathrm{H}, \mathrm{CH}_{2} \mathrm{O}$, and $\mathrm{HO}_{2}, \mathrm{CH}_{3} \mathrm{O}_{2}, \mathrm{OH}, \mathrm{HCOOH}$ (Figure 5b) (initialized to zero), are chemically produced in gas phase and/or aqueous phase. The highest values of $\left[\mathrm{CH}_{3} \mathrm{O}_{2} \mathrm{H}\right]_{\mathrm{g}}$ are observed at the top of the mountain in the interstitial air of the cloud.

On the contrary, $\mathrm{CH}_{3} \mathrm{O}_{2}, \mathrm{HO}_{2}$ and $\mathrm{OH}$ species that are produced in gas phase before entering the cloud in concentrations of $8 \mathrm{ppt}, 15 \mathrm{ppt}$, and $0.1 \mathrm{ppt}$, respectively, are 
c
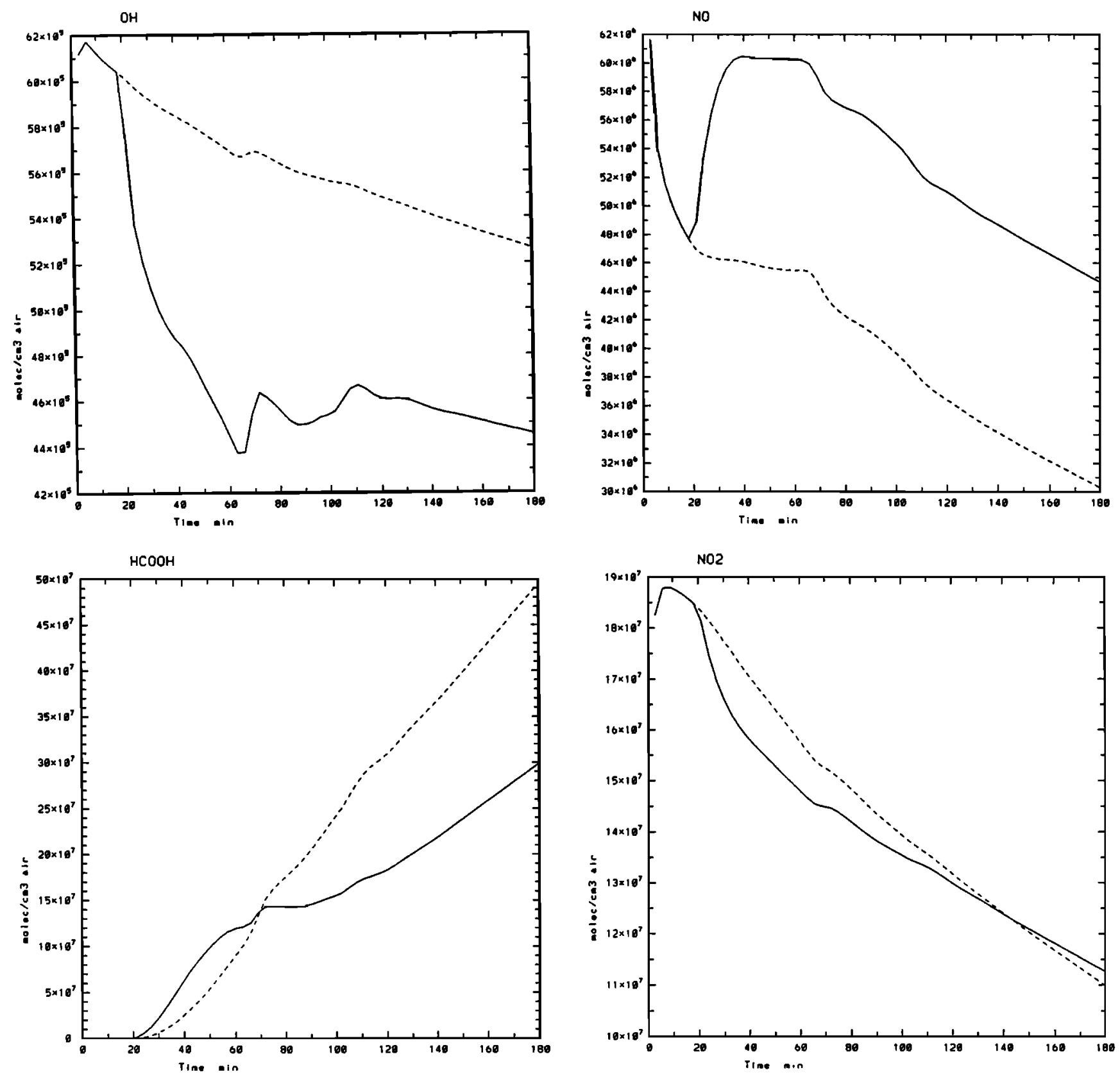

Figure 4. (continued)

Table5. Values of the sticking coefficients

\begin{tabular}{ccc}
\hline Species & \multicolumn{1}{c}{ Sticking coefficient } & Reference \\
\hline $\mathrm{O}_{3}$ & $2 \mathrm{E}-3$ & Utter etal. [1992] \\
$\mathrm{H}_{2} \mathrm{O}_{2}$ & 0.18 & Ponche et al. [1993] \\
$\mathrm{CH}_{3} \mathrm{O}_{2} \mathrm{H}$ & 0.05 & Worsnop etal. [1992] \\
$\mathrm{CH}_{2} \mathrm{O}$ & 0.05 & Lelieveld and Crutzen [1991] \\
$\mathrm{HNO}_{3}$ & 0.125 & Van Doren et al. [1990] \\
$\mathrm{HO}_{2}$ & 0.2 & Lelieveld and Crutzen [1991] \\
$\mathrm{OH}_{\mathrm{H}}$ & 0.05 & Lelieveld and Crutzen [1991] \\
$\mathrm{NO}_{2}$ & $6.3 \mathrm{E}-4$ & Lelieveld and Crutzen [1991] \\
$\mathrm{NO}$ & $1 \mathrm{E}-4$ & Lelieveld and Crutzen [1991] \\
$\mathrm{CH}_{3} \mathrm{O}_{2}$ & 0.05 & Lelieveld and Crutzen [1991] \\
$\mathrm{HCOOH}$ & 0.05 & Lelieveld and Crutzen [1991] \\
\hline
\end{tabular}

efficiently depleted up to $95 \%, 86 \%$, and $50 \%$ of these values. Such depletion of $\mathrm{OH}$ has already been found by previous authors [Lelieveld and Crutzen, 1990]. OH is less soluble than the radicals and part of its depletion is due to the depletion of $\mathrm{H}_{2} \mathrm{O}_{2}$ because of the reaction $\mathrm{G5}$ (see Table 1). $\mathrm{CH}_{2} \mathrm{O}$ gas mixing ratio (in parts per billion) decreases by almost a factor of 2 from the upstream region to the cloudy one. $\mathrm{NO}$ and $\mathrm{NO}_{2}$ govem the ozone budget. To appreciate whether the cloud has an impact on the conversion of NO to $\mathrm{NO}_{2}$, the ratio [NO]/[NO $\left.{ }_{2}\right]$ has been plotted (Figure 6). Both upstream and downstream, outside the cloud, the ratio is 0.5 . It increases to 0.65 in the middle of the cloud. One can notice that the perturbed [NO]/[NO $]$ isolevels follow the isolevels of cloud water mixing ratio, except on the downwind slope of the 

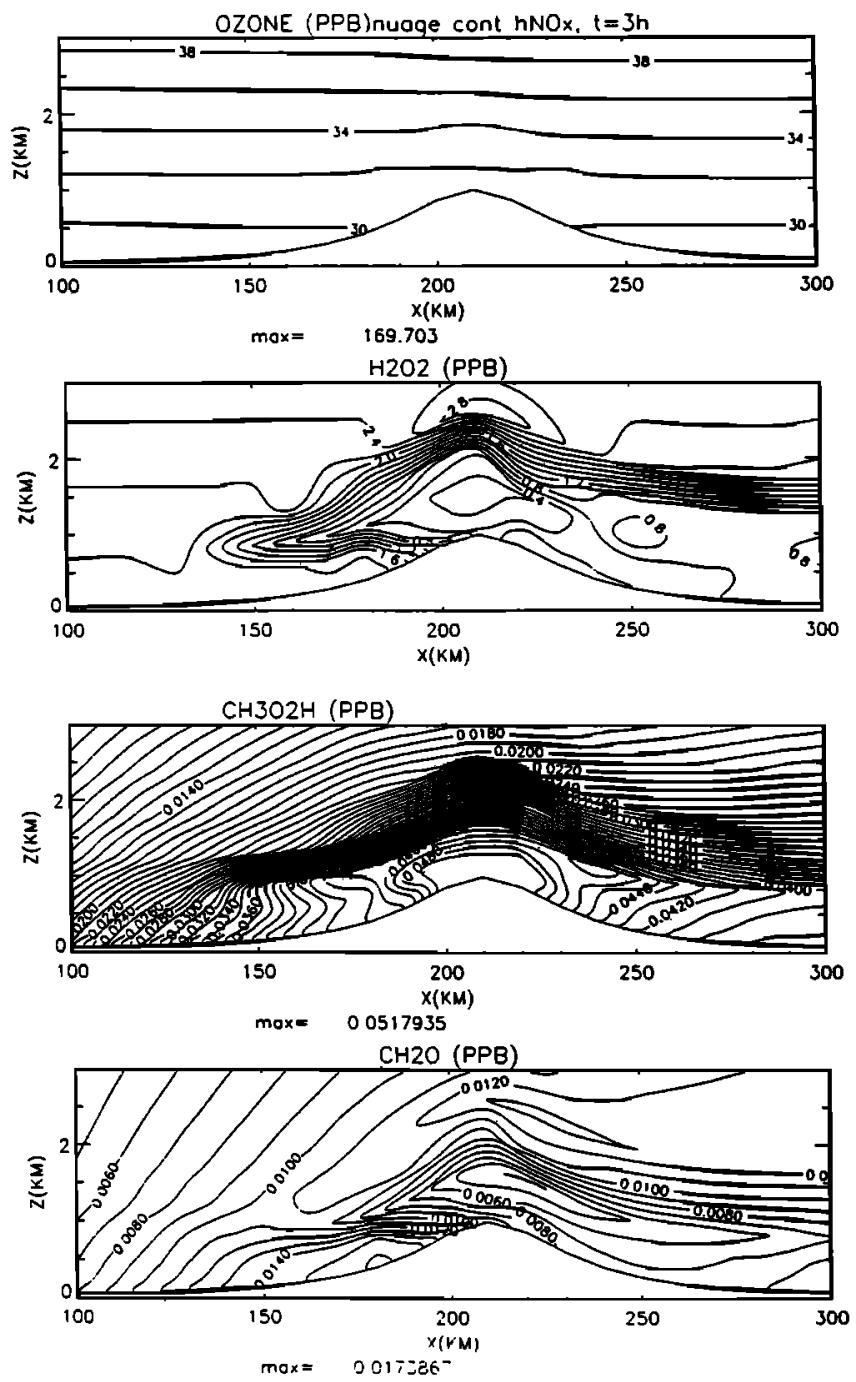
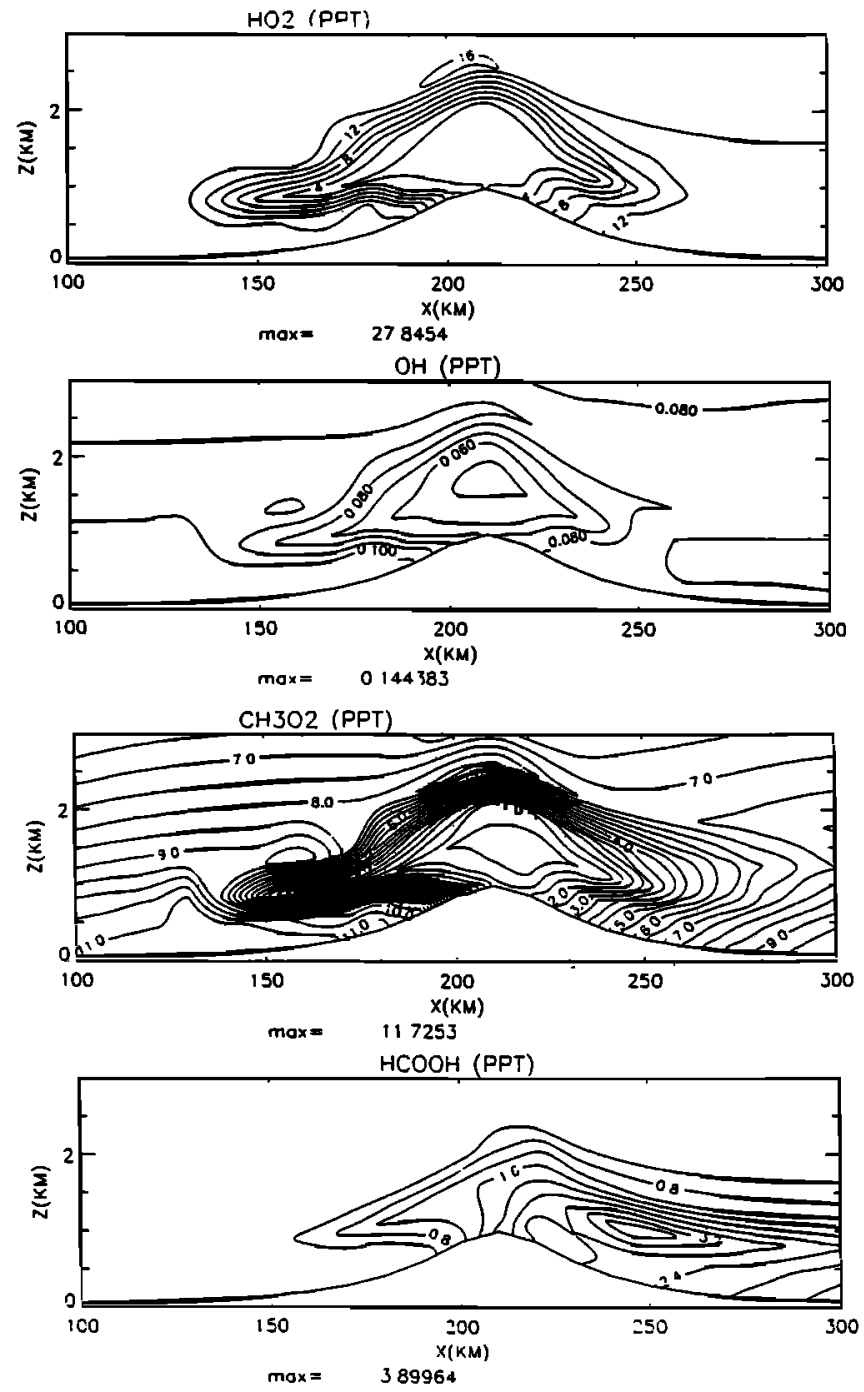

Figure 5. (a) Continental cloud ; $\mathrm{O}_{3}, \mathrm{H}_{2} \mathrm{O}_{2}, \mathrm{CH}_{3} \mathrm{O}_{3} \mathrm{H}$ and $\mathrm{CH}_{2} \mathrm{O}$ gas concentrations, (time=3hours). (b) Continental cloud ; $\mathrm{HO}_{2}, \mathrm{CH}_{3} \mathrm{O}_{2}, \mathrm{OH}, \mathrm{HCOOH}$ gas concentrations, (time=3hours).

mountain where below the cloud [NOJ/[NO ${ }_{2}$ ratio still shows an effect. On the upwind side of the mountain, the [NO]/[NO ${ }_{2}$ ] isolevels match those of the mixing ratio (Figure 2a) drawn for values greater than or equal to $0.1 \mathrm{~g} / \mathrm{kg}$. This is likely due to the advection of the small drops on the lee side.

Hence, the presence of the cloud leads to a decrease in gaseous concentrations of most of the species, except for $\mathrm{CH}_{3} \mathrm{O}_{2} \mathrm{H}$ which is enhanced. As $\mathrm{OH}$ is involved as a reactant in most of all the gas phase chemical reactions its depletion into the cloud (up to $50 \%$ of the upstream value) has strong consequences for other moderately soluble species like $\mathrm{CH}_{3} \mathrm{O}_{2}, \mathrm{HO}_{2}$, via the reactions $\mathrm{G} 7, \mathrm{G} 10, \mathrm{G11}, \mathrm{G} 14$. A decrease of the production rate of the peroxyl radicals due to the depletion of $\mathrm{OH}$ likely contributes to their depletion. The gas phase production of $\mathrm{CH}_{3} \mathrm{O}_{2} \mathrm{H}$ depends on $\mathrm{HO}_{2}$ and $\mathrm{CH}_{3} \mathrm{O}_{2}$ (reaction $\mathrm{G8}$ ) while its destruction depends mainly on $\mathrm{OH}$ (reactions $\mathrm{G} 10$ and G11). Although $\mathrm{HO}_{2}$ and $\mathrm{CH}_{3} \mathrm{O}_{2}$ are efficiently depleted, the inhibition of the reactions $\mathrm{G}^{2} 0^{2}$ and G11 by the removal of $\mathrm{OH}$ from gaseous phase is even more efficient, leading to an increase of the gaseous concentrations of $\mathrm{CH}_{3} \mathrm{O}_{2} \mathrm{H}$. On the other hand, the efficient production of an aqueous phase certainly contributes to the occurrence of the highest gas concentrations in the middle part of the cloud. Owing to its low solubility, the net amount of this species produced in cloud water is immediately released from the aqueous phase. As previously said in the introduction, it is also the depletion of $\mathrm{HO}_{2}$ and $\mathrm{CH}_{3} \mathrm{O}_{2}$ that is responsible for the variations of the ratio $[\mathrm{NO}] /\left[\mathrm{NO}_{2}\right]$ because $\mathrm{NO}$ and $\mathrm{NO}_{2}$ have very low solubilities. This is done via the reactions G18 and G19.

$\mathrm{HCOOH}$ is essentially produced in aqueous phase. Hence, it begins to appear in gas phase in the interstitial air of the cloud and its maximum gaseous phase concentration (3.9 ppt) is found downwind where evaporation of cloud droplets has occurred releasing $\mathrm{HCOOH}$ into the air.

Polydisperse cloud : maritime case. From these results, one could expect that a different scavenging of radicals may lead to another behavior. The simulated maritime cloud has almost the same total liquid water content, in order to examine the influences of both the partitioning in two different drop- 
size populations, and of the precipitation. For this purpose, the relative difference (expressed in percent) of the gas phase concentrations between the two cloud cases have been plotted (Figure 7). The continental case has been chosen as the reference. The Figure 7a clearly shows that $\mathrm{CH}_{2} \mathrm{O}, \mathrm{HO}_{2}$ are the most sensitive species to the cloud type. $\mathrm{CH}_{3} \mathrm{O}_{2} \mathrm{H}, \mathrm{OH}$, $\mathrm{H}_{2} \mathrm{O}_{2}$ gas mixing ratios (Figures $7 \mathrm{~b}, 7 \mathrm{c}$ ) differ from the continental case primarily on the downwind side. The relative differences reach, respectively, $6 \%, 20 \%$ and $80 \%$, in an order that follows the increasing solubility of these species. $\mathrm{CH}_{3} \mathrm{O}_{2} \mathrm{H}$ gas mixing ratio is slightly lower in the maritime case and the difference with respect to the continental case is maximized on the downwind side. For the first part of the downwind slope of the mountain, $(X<240 \mathrm{~km})$ OH gas mixing ratio is higher in the maritime case, becoming lower downstream. The maximum difference with respect to the continental case is reached far downstream $(X=270 \mathrm{~km})$. Near the top of the mountain, $(X=210 \mathrm{~km}$ and $220 \mathrm{~km})$, the $\mathrm{OH}$ mixing ratio is (up to $12 \%$ ) higher in the maritime case. Ten and twenty kilometers farther downstream, a strikingly
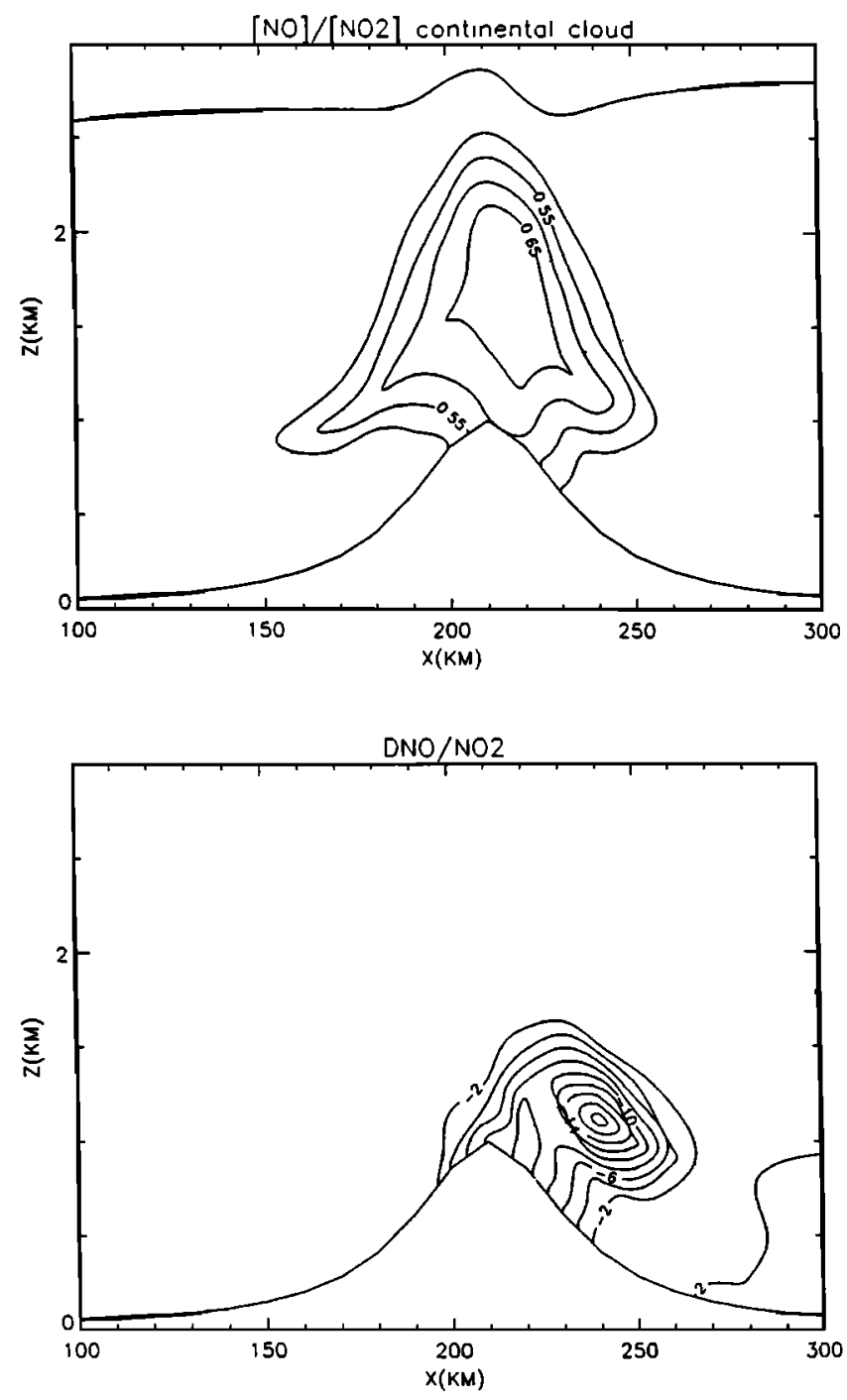

Figure 6. (top) continental cloud; [NO]/[NO $]$, (time=3hours); (bottom) relative difference of the $[\mathrm{NO}] /\left[\mathrm{NO}_{2}\right]$ ratio between the maritime case and the continental case (expressed in percent; continental case taken as reference).
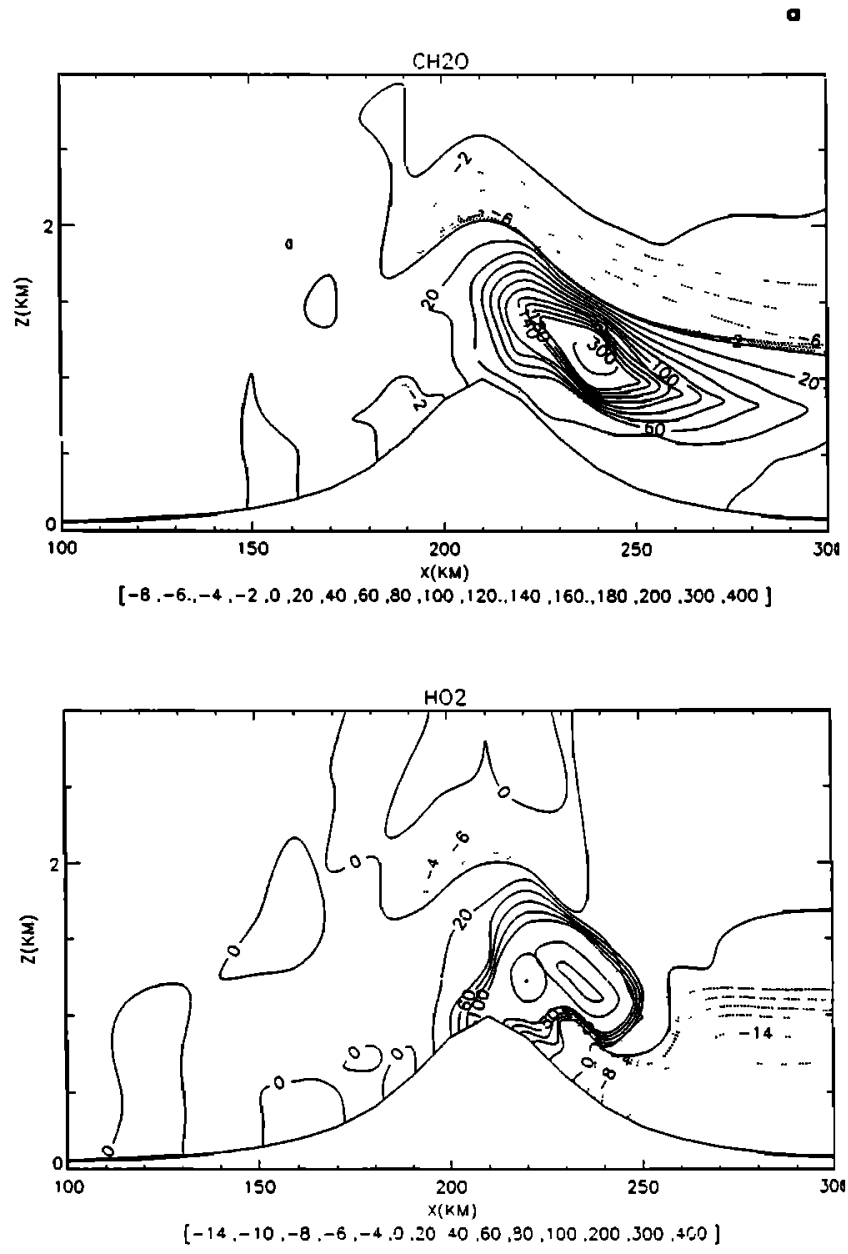

Figure 7. Relative differences between the maritime case and the continental case (expressed in percent; continental case taken as reference) (a) $\mathrm{CH}_{2} \mathrm{O}, \mathrm{HO}_{2}$; (b) $\mathrm{CH}, \mathrm{O}_{2} \mathrm{H}, \mathrm{OH}$ and (c) $\mathrm{CH}_{3} \mathrm{O}_{2}, \mathrm{H}_{2} \mathrm{O}_{2}$.

different behavior is observed in the vertical direction. In the maritime case, between altitudes of $1.5 \mathrm{~km}$ and $1 \mathrm{~km}$ the mixing ratio is higher ( $X=230 \mathrm{~km}$ and $X=240 \mathrm{~km}$ ) while below $1 \mathrm{~km}$ they are lower. According to the evolution of cloud and rain waters (Figure 2) this modification corresponds to a difference in drop-size populations. At these locations, the continental cloud is evaporating with no more cloud water below the altitude $1 \mathrm{~km}$, whereas the maritime cloud, with no more cloud water since $1.5 \mathrm{~km}$ high, is only experiencing precipitation. Hence, in the continental case, between $1 \mathrm{~km}$ up to $1.5 \mathrm{~km}, \mathrm{OH}$ is efficiently removed from gas phase and released at lower locations or downstream $(X>240 \mathrm{~km})$ while it is drained off by precipitation in the maritime case. Far downstream, even if there is no more precipitating water, the recovery in the maritime case is slower than in the continental case. Therefore, the differences between the two cloud cases increase downstream $(X>250 \mathrm{~km})$ owing to the wash out of $\mathrm{OH}$ and $\mathrm{HO}_{2}$. Here one again finds an indirect effect of the radicals: the recovery of the main gaseous phase reactant $\mathrm{OH}$ is delayed because of their scavenging/wash-out.

$\mathrm{HO}_{2}$ experiences the same evolution as $\mathrm{OH}$ from upstream to downstream. However, the difference between the two cloud cases is more drastic for $\mathrm{HO}_{2}$ than for $\mathrm{OH}$. About the 
b
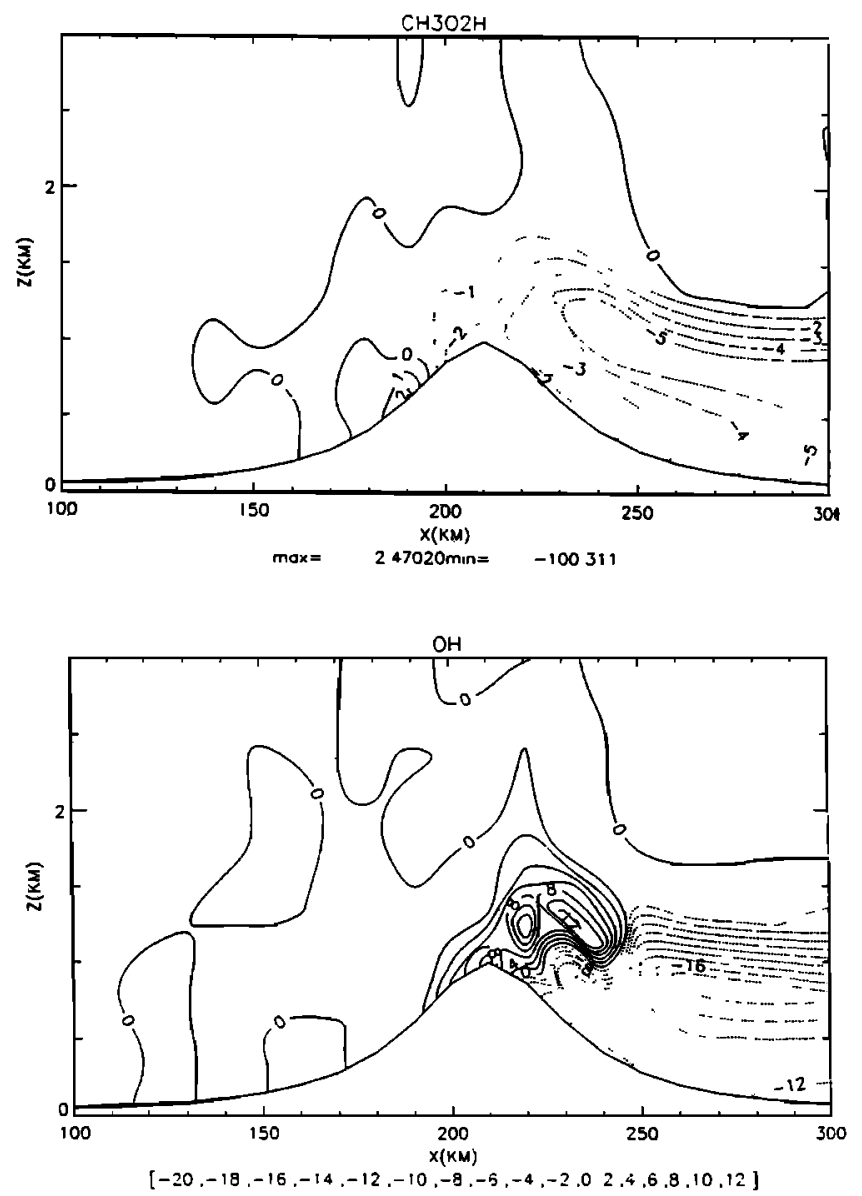
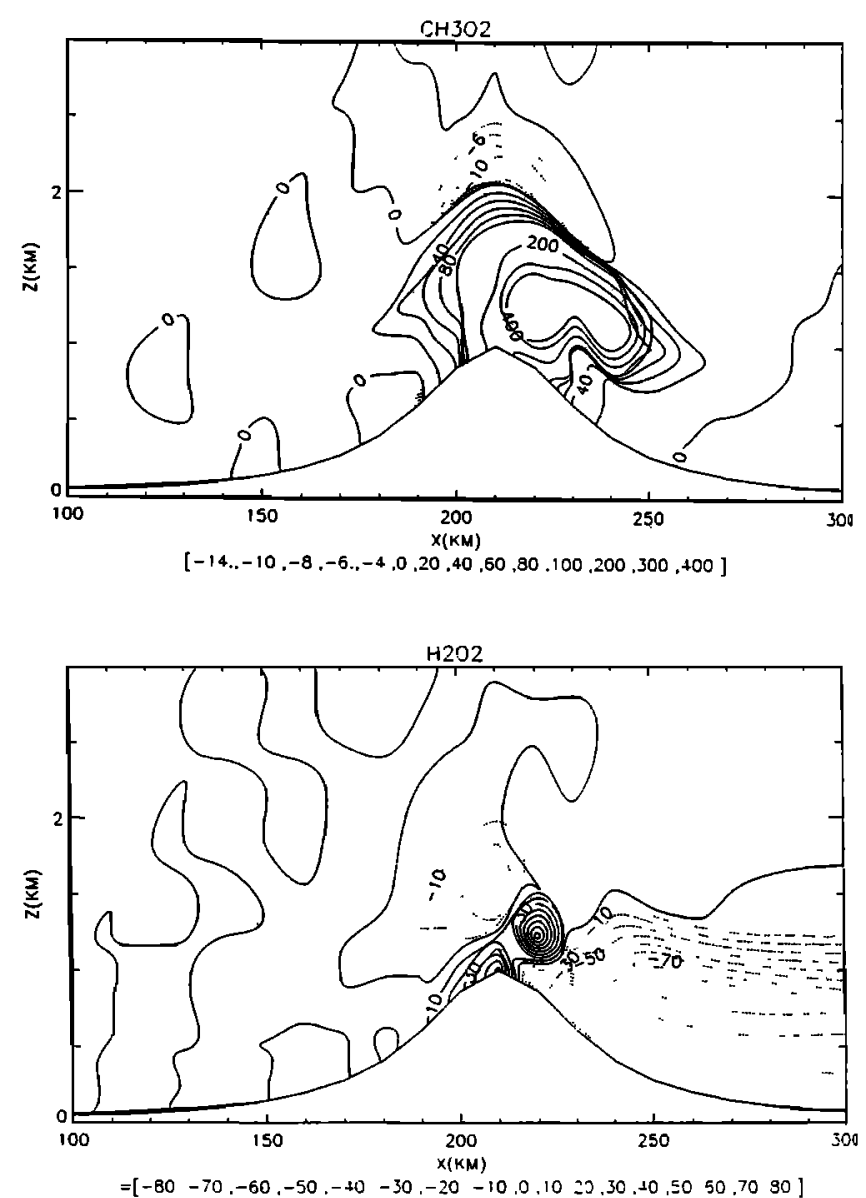

Figure 7. (continued)

locations $X=220 \mathrm{~km}, \mathrm{HO}_{2}$ maritime gaseous mixing ratio is up to 4 times greater than in the continental-cloud case. For $\mathrm{H}_{2} \mathrm{O}_{2}$, the absolute magnitude of deviation of the maritime case from the continental case is as great $(80 \%)$ around the top of the mountain (positive difference) as far downstream (negative difference). $\mathrm{H}_{2} \mathrm{O}_{2}$ has spatially a slightly different behavior than $\mathrm{OH}$ and $\mathrm{HO}_{2}$ because its variations are essentially driven by its high solubility.

The sensitivity of $\mathrm{CH}_{2} \mathrm{O}$ to the cloud type is noticeably different from these three last species. Although the maximum difference is reached around $X=230 \mathrm{~km}, 240 \mathrm{~km}$ (with higher concentrations in the maritime case) for the flow that enters the center of the cloud, significant differences are observed downstream. Along the flow that passes through only the highest part of the cloud without any rainwater, a slight difference is observed in gas concentrations of $\mathrm{CH}_{2} \mathrm{O}$ with slightly greater concentrations in the continental case. This feature also remains far downstream. $\mathrm{CH}_{3} \mathrm{O}_{2}$ also follows the same behavior (Figure 7c). In the upper part of the clouds, $\mathrm{CH}_{3} \mathrm{O}_{2}$ is more efficiently scavenged by the maritime cloud whereas below $2 \mathrm{~km}$, its gas mixing ratio is higher in the maritime case with a maximum difference centered at $X=230$ $\mathrm{km}$. However, as opposed to $\mathrm{CH}_{2} \mathrm{O}$, after $X=250 \mathrm{~km}$ the differences between the two cloud-cases disappear for $\mathrm{CH}_{3} \mathrm{O}_{2}$.

Hence, the greatest differences are observed for the species $\mathrm{CH}_{3} \mathrm{O}_{2}, \mathrm{CH}_{2} \mathrm{O}$ and $\mathrm{HO}_{2}$. Their gaseous mixing ratios in most parts of the maritime cloud are above those of the continental case. Differences up to $300-400 \%$ are located on the downwind side of the mountain. This strong effect can not be explained by only the solubility of the species since $\mathrm{CH}_{3} \mathrm{O}_{2}$, for example, being less soluble than $\mathrm{H}_{2} \mathrm{O}_{2}$, seems to have a higher sensitivity to the cloud type.

The difference is greatest and positive downstream where the continental cloud water evaporates, while the maritime cloud is reduced to only precipitating rainwater. The zone with positive differences is located where rainwater is present both upstream and downstream. However, whereas the distribution of $q_{r w}$ is symmetric with respect to the top of the mountain (see Figure 2), the maximum difference of the gaseous concentrations is shifted to the downwind side. While continental cloud water remains on the downwind side, maritime cloud water has given way to rainwater with large drops. Moderately soluble species like $\mathrm{CH}_{3} \mathrm{O}_{2}$, and $\mathrm{HO}_{2}$ more rapidly reach their equilibrium between phases than higher soluble species like $\mathrm{H}_{2} \mathrm{O}_{2}$. For these moderate soluble species, the drop-size sensitivity cannot explain such a difference between the two cloud cases. On the other hand, a sensitivity to the bulk water content is likely responsible for gaseous mixing ratios of these species being greater in the maritime case than in the continental one. In fact, on the downwind slope, the amount of liquid water in the form of rain is weak compared to that of the continental cloud $\left(q_{\mathrm{cw}}>0.1 \mathrm{~g} / \mathrm{kg}\right.$ at 
$X=240 \mathrm{~km}$ and $q_{r w}$ is about $0.06 \mathrm{~g} / \mathrm{kg}$ ). Therefore, the rapid decrease of the rainwater content downwind leads to higher $\mathrm{CH}_{3} \mathrm{O}_{2}, \mathrm{OH}$ and $\mathrm{HO}_{2}$ mixing ratios. The other reason is the decrease of the gas phase production of these species as a feedback consequence of the depletion of $\mathrm{OH}$.

Observation of higher radicals concentrations in the maritime case supports a decrease of the $[\mathrm{NO}] /\left[\mathrm{NO}_{2}\right]$ ratio. Reaction G19 for the conversion of NO into $\mathrm{NO}_{2}$ is favored compared to the continental case (Figure 6b). In the maritime case, $\left[\mathrm{NO}_{2}\right]$ is higher, while [NO] is lower.

The enhanced G19 reaction produces more formaldehyde $\mathrm{CH}_{2} \mathrm{O}$. Therefore, for $\mathrm{CH}_{2} \mathrm{O}$ downstream, we observe a longer extent of the deviation from the continental case than for $\mathrm{CH}_{3} \mathrm{O}_{2}$, even far away from rain. One could expect that because $\mathrm{CH}_{2} \mathrm{O}$ is a soluble species of the chemical system (after the acids), increased gas phase production would lead to an increase of its aqueous concentrations until Henry's law is reached. However, the process of mass transfer is governed by the term $L k_{t}$ in the equations. Figure 8 presents the transfer of $\mathrm{H}_{2} \mathrm{O}_{2}$ to cloud water and to rainwater $(\alpha=0.2)$ for the case of the maritime cloud. Leaving aside the dependence on $\alpha$ of $L k$, this figure shows the transfer speed of a species, regardless of its solubility, as a function of the combined variation of the liquid water content LWC and the drop size. Clearly, the transfer is more rapid toward cloud water than toward rain. Particularly, the transfer rate decreases around $X=240 \mathrm{~km}$ where liquid water is almost solely composed of rainwater with large drops. Compared to $X=210 \mathrm{~km}$, there is a 100 -fold difference between these two speeds. This variation of the transfer speed to aqueous phase with the drop size explains why, experimentally, cloud water is found to be more concentrated in acids than rainwater.

The impact of the term $\mathbf{L k}_{\mathrm{t}}$ decreases with the solubility of the species because the transfer is limited overall by the solubility (Henry's law). It becomes important in the case of highly soluble species like $\mathrm{CH}_{2} \mathrm{O}$ and $\mathrm{H}_{2} \mathrm{O}_{2}$. The differences of behaviors between the two radicals is likely due to the aqueous reactions : $\mathrm{A7}$ and $\mathrm{A8}, \mathrm{HO}_{2}$ being more rapidly destroyed in aqueous phase than $\mathrm{CH}_{3} \mathrm{O}_{2}$.

The concentrations in rainwater of $\mathrm{OH}, \mathrm{CH}_{3} \mathrm{OOH}$, NO, $\mathrm{CH}_{2} \mathrm{O}, \mathrm{H}_{2} \mathrm{O}_{2}$ and $\mathrm{HCOOH}$ are given in molecules per volume

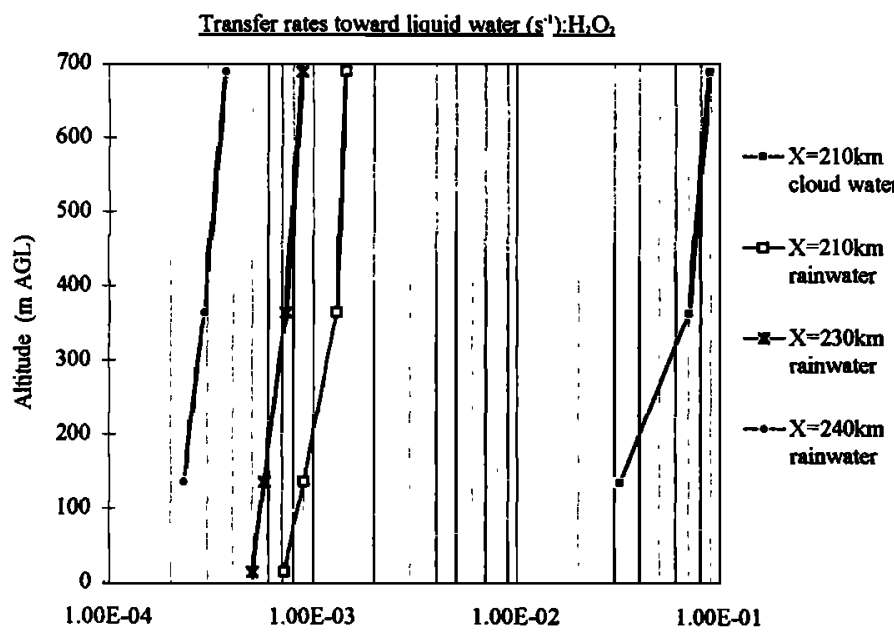

Figure 8. Transfer rate $L k$, toward liquid water (cloud and rainwater) at various locations along the mountain, maritime case, $\alpha=0.2$. of water (cubic centimeters) in Figures $9 a$ and $9 b$ for different vertical sections along the mountain. $\mathrm{OH}, \mathrm{CH}_{3} \mathrm{OOH}$, and $\mathrm{NO}$ show common features: except for the incipient raindrops on the upstream edge of the cloud, their concentrations in rainwater do not vary along the mountain. The behavior of $\mathrm{HCOOH}, \mathrm{CH}_{2} \mathrm{O}$, and $\mathrm{H}_{2} \mathrm{O}_{2}$ is quite different than that of the former species. Their rainwater concentrations decrease from almost the middle of the mountain to the right side. Far downwind, the raindrops are diluted by a factor of 10 relative to their upwind concentrations.

\section{Deviations From Henry's Law}

Winiwarter et al. [1992] reported that sampling in a chemically homogeneous droplet population in a cloud system where the liquid water content varies with time leads to subsaturation of the aqueous phase for nondissociating species. Pandis and Seinfeld [1992] gave additional explanations for the results of these samplings. Independent of sampling duration, the variation with time of the LWC is, in their case, the main reason for producing an apparent deviation from Henry's law equilibrium due to the non linearity of the aqueous sampling (samplings on discontinuous time intervals).

Most of the theoretical discussions to explain deviations from Henry's law [Pandis and Seinfeld, 1992] take place in the context of a system which is characterized by (1) a constant gas concentration of the species, (2) all droplets of the same size have the same aqueous phase concentration at the same moment, (3) the system is spatially homogeneous and Henry's law equilibrium is obeyed at any moment. Furthermore, (4) they assume that no mass exchange occurs between the bulk sample and the atmosphere. However, the first assumption does not remain valid as soon as some removal processes (by rain for example) exist. In addition, since real clouds are composed of a large range of drop sizes, whether or not processes like precipitation and evaporation are active, assumptions (2) and (3) cannot hold anymore.

Hence, measurements in polydisperse clouds can lead to deviations from Henry's law for the bulk sampling which vary with the location in the cloud. In monodisperse clouds (continental cloud in our case) one may surmise that sampling in the middle of the cloud or on the edges would give the same results. This is what we seek to verify. The ratio

$\mathrm{C}_{\mathrm{aq}} / \mathrm{LH}_{\mathrm{eff}} \mathrm{RTC}_{\mathrm{g}}$ gives a measure of the deviation from Henry's law. $C_{a q}$ can be either the cloud water concentration or the rainwater concentration (molec per cubic centimeter air) and $L$ the corresponding liquid water content. This ratio has been plotted for both the soluble species $\mathrm{H}_{2} \mathrm{O}_{2}$ (Figure 11) and $\mathrm{HCOOH}$ (Figure 10). The formic acid is produced mainly in aqueous phase, while $\mathrm{H}_{2} \mathrm{O}_{2}$ is essentially produced in gas phase. This characteristic could lead to a completely different response to variations of liquid water contents and drops size. In the case of a species mainly produced in gas phase, this ratio can have a value less than 1 due to by one of the following events : (1) - Gas phase production rate faster than the transfer to aqueous phase, (2) - effect of large drops or increasing drop size, (3) - effect of evaporation (primarily valid in the case of cloud water). On the other hand, a ratio greater than 1 could be caused by either decreasing LWC or increasing the aqueous production. For soluble species 
-
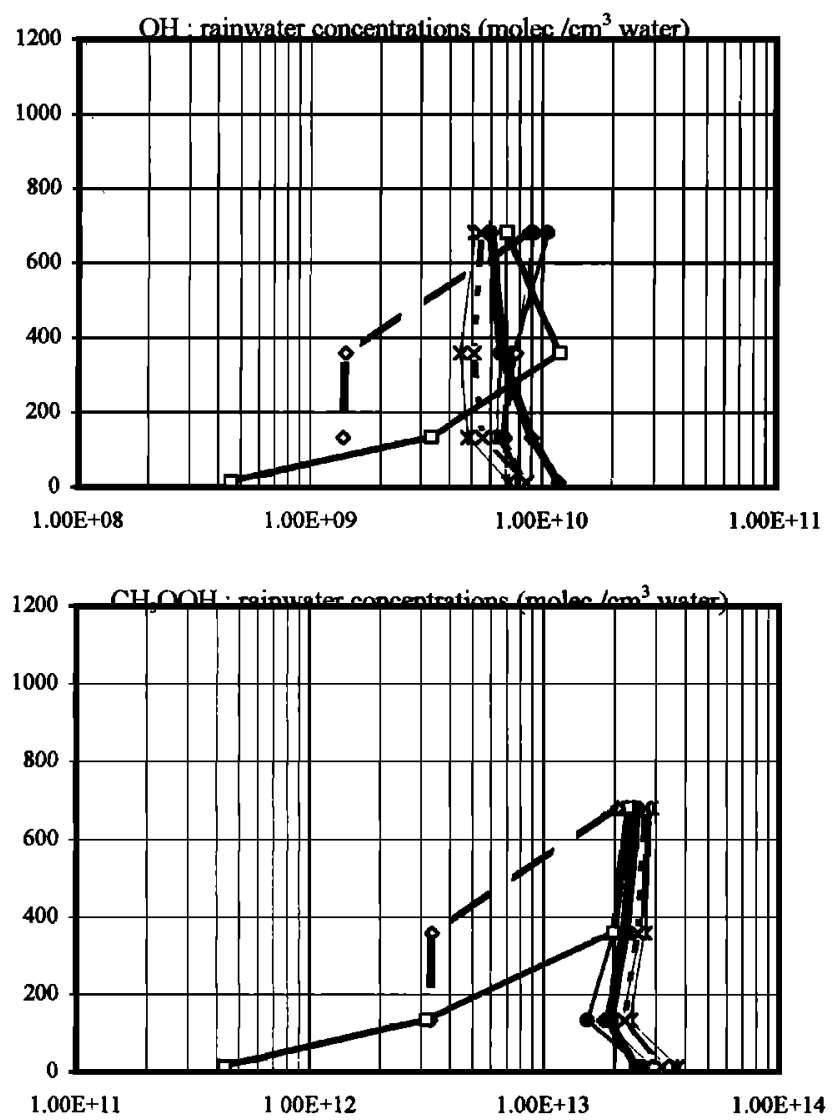

$\mathrm{CH}_{2} \mathrm{O}$ rainwater concentrations (molec $/ \mathrm{cm} 3$ water)

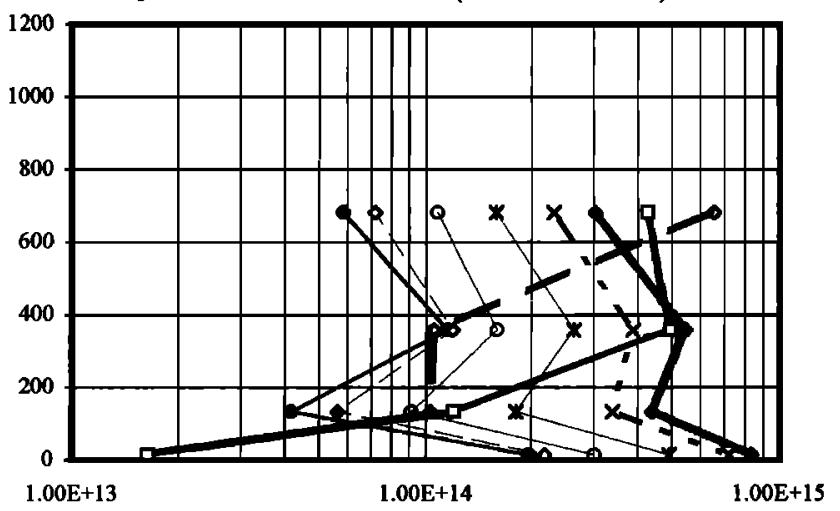

$\mathrm{H}_{2} \mathrm{O}_{2}$ : rainwater concentrations (molec $/ \mathrm{cm}^{3}$ water)
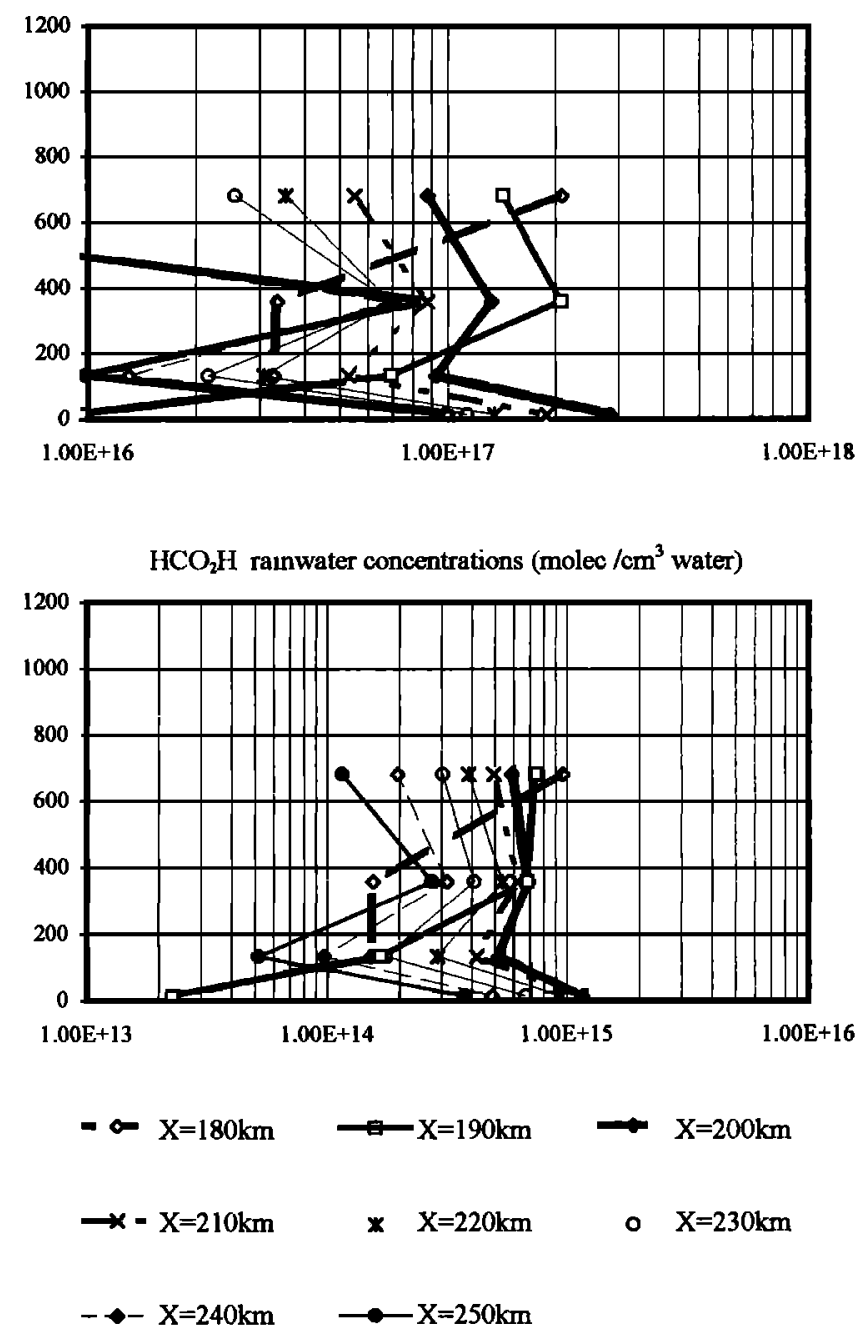

Figure 9. Maritime case ; Rainwater concentrations given in molec per cubic centimeter of water.

principally produced in aqueous phase, a ratio greater than 1 most likely comes rather from an increase of aqueous production, while a ratio smaller than 1 means either (1) a decrease of aqueous production, (2) a non equilibrium due to large drops, (3) an increasing transfer to gas phase (evaporation), and (4) an enhanced gas phase production.
HCOOH. The ratios are given for the continental cloud water $\left(q_{l c}\right)$ and maritime cloud water $\left(q_{l m}\right)$ and rainwater $\left(q_{2}\right)$. Here $q_{l c}$ is greater than or equal to 1 over the entire continental cloud. More precisely, as long as one goes downstream, this ratio tends to 1 . Henry's law equilibrium is reached in the middle of the cloud. On the cloud's edges, $q_{1 c}$, 

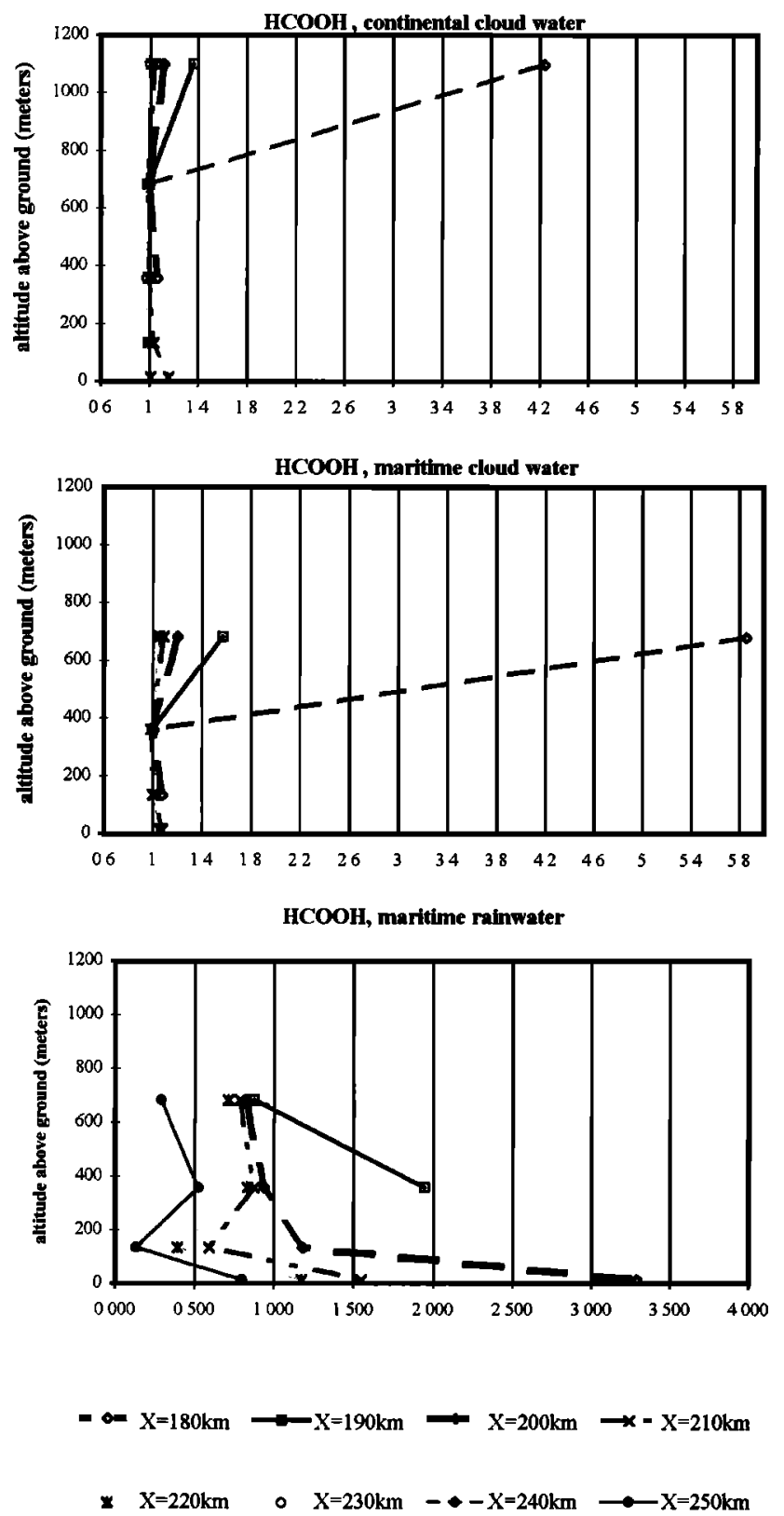

Figure 10. Deviations from Henry's law of $\mathrm{HCOOH}$ : (top) Continental cloud water, (middle) Maritime cloud water and (bottom) Maritime rainwater.

for both top and bottom is greater than 1 . This is likely due to the surrounding air which acts as an important gaseous source for HCOOH's precursors $\mathrm{CH}_{3} \mathrm{O}_{2}, \mathrm{OH}$ which are moderately soluble species. Further into the cloud, the interstitial air composition of these precursors is smaller. Hence, on the edges of the cloud the aqueous production of $\mathrm{HCOOH}$ is very efficient. This effect decreases from upwind $(X=180 \mathrm{~km})$ to the top of the mountain $(X=210 \mathrm{~km})$. Downstream, $(X=220 \mathrm{~km}$ or $230 \mathrm{~km}$ ), HCOOH maintains Henry's law equilibrium while LWC decreases, which could induce an increase of $q_{l c}$. This reflects its rather low sensitivity to evaporation.

In the case of the maritime cloud, $q_{l m}$ deviates from Henry's law in parts of cloud where rain is present. Vertically, LWC decreases not only because of evaporation but mainly because of the conversion of cloud water into rainwater. This corresponds to the case of an open system as studied by Pandis and Seinfeld [1992], where a decrease of LWC leads to an increase of $q_{1 m}$. No more mass exchange is enhanced from aqueous phase to the air, as it is done in the case of a decrease of LWC by evaporation.

The ratio for maritime rainwater shows a clear tendency: upstream it is greater than 1 , while downstream it is smaller. Upstream, the raindrops are still small (less than 100 microns) and the incipient raindrops coming from cloud droplets already contain excess formic acid with respect to Henry's law. Downstream, there is no more cloud water and the ratio smaller than 1 reflects a sensitivity to the raindrops size which has increased drastically.
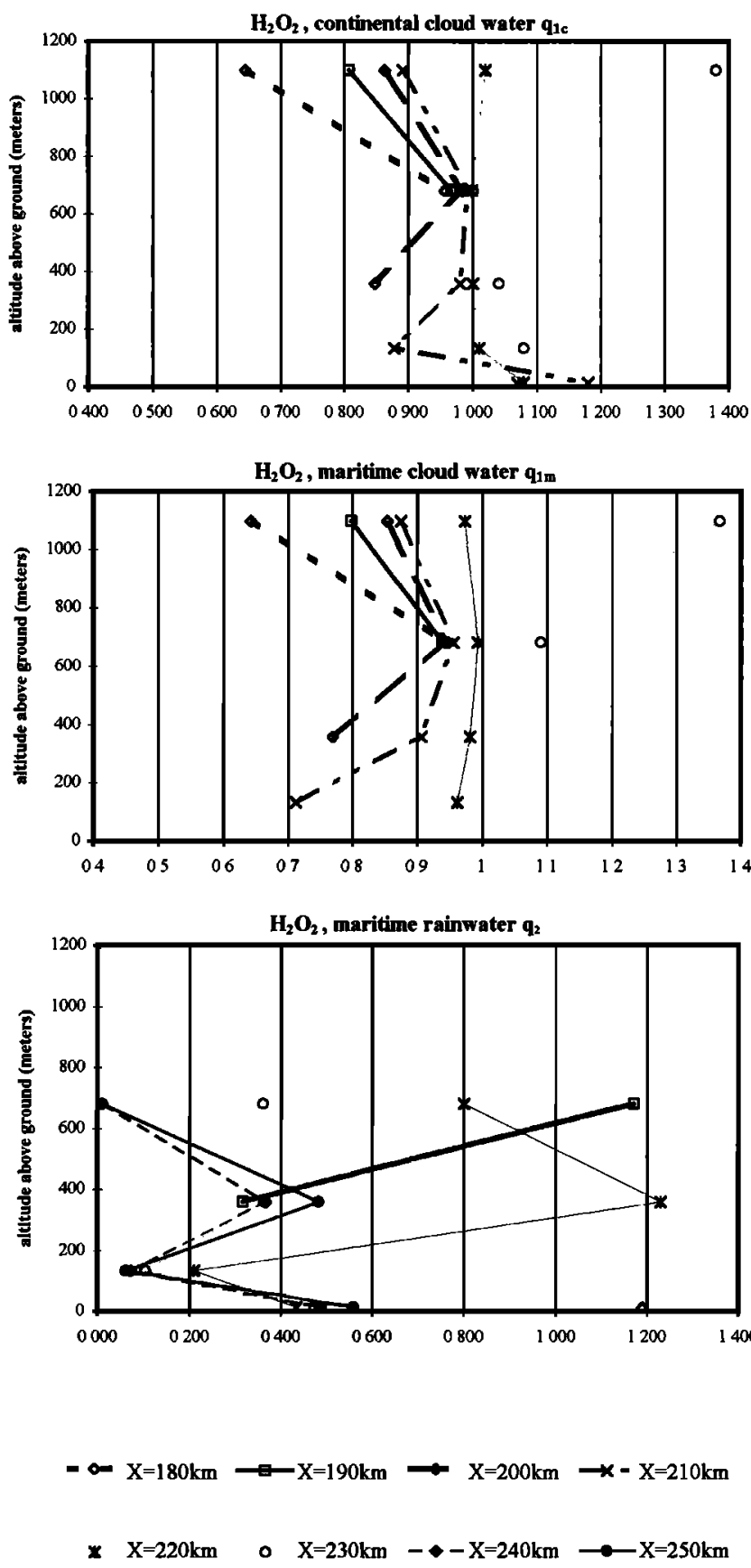

Figure 11. Deviations from Henry's law of $\mathrm{H}_{2} \mathrm{O}_{2}$ : (top) Continental cloud water, (middle) Maritime cloud water and (bottom) Maritime rainwater. 
$\mathbf{H}_{2} \mathbf{O}_{2}$. For the continental case, a deviation from Henry's law already distinguishes the behavior of $\mathrm{H}_{2} \mathrm{O}_{2}$ from that of $\mathrm{HCOOH}$. Most of the droplets are subsaturated except far downstream where cloud evaporation occurs and droplets are then supersaturated according to Henry's law. $\mathrm{H}_{2} \mathrm{O}_{2}$ shows an analogous behavior in maritime cloud water. In maritime rainwater, drops on the upwind side $(X \leq 220 \mathrm{~km})$ are supersaturated in the upper part of the cloud. In all remaining parts of the cloud, raindrop concentrations of $\mathrm{H}_{2} \mathrm{O}_{2}$ are very low under Henry's law values (about 0.2 times smaller). This deviation from Henry's law is likely due to the increase of raindrops size which is more important than that shown by $\mathrm{HCOOH}$.

$\mathrm{HO}_{2}, \mathrm{CH}_{2} \mathrm{O}, \mathrm{CH}_{3} \mathrm{O}_{2} \mathrm{H}$. Deviations from Henry's law are given for the maritime cloud case in Table 6. Clearly, it appears that the very low soluble species $\mathrm{CH}_{3} \mathrm{O}_{2} \mathrm{H}$ follows Henry's law both in cloud water and rainwater, while the formaldehyde and the peroxy radical show different behaviors. The formaldehyde is almost at Henry's law concentrations in cloud water whereas $\mathrm{HO}_{2}$ already deviates from this law. Both of them undergo deviations for rainwater concentrations due to their solubilities. For $\mathrm{HO}_{2}$ this noticeable deviation in cloud water is likely due to its destruction in aqueous phase (reaction A7, Table III) which is considerably faster than in gas phase (reaction G4). That leads to those unbalanced gaseous and aqueous concentrations of $\mathrm{HO}_{2}$ compared to what Henry's law would predict. The case of $\mathrm{HO}_{2}$ is of particular interest and illustrates well how the aqueous chemical reactivity moves concentration out of Henry's law equilibrium.

\section{Summary and Discussion}

In this paper we dealt with the effect of polydisperse clouds on some of the main ozone precursors. In the box model, the variations of liquid water content with time was taken as one near the middle of the maritime cloud on the top of the mountain. The box-model runs with two different drop sizes (20 or 200 microns of diameter) provide qualitative informations about the sensitivities of the species to this parameter and how they are modified. The first run was designed to simulate a population of small drops (cloud water or continental clouds) while the second run was intended to represent a population of exclusively large drops (rainwater).

The main results are as follows: (1) Ozone and $\mathrm{CH}_{3} \mathrm{O}_{2} \mathrm{H}$ are almost unaffected by the presence of liquid water; (2) $\mathrm{A}$ lower $[\mathrm{NO}] /\left[\mathrm{NO}_{2}\right]$ ratio in the case of a large-drop population, which means an enhanced gaseous production of formaldehyde ; (3) The second point induces different sensitivities of $\mathrm{NO}$ and $\mathrm{NO}_{2}$, because of the increasing importance of the reactions G18 and G19 with drop size ; (4) Points 2 and 3 are the consequences of the depletion of radicals $\mathrm{HO}_{2}$ and $\mathrm{CH}_{3} \mathrm{O}_{2}$ in the gas phase. Hence, although they are moderately soluble, they are the driving species of this chemistry including aqueous phase.

The comparison between the continental-cloud case and the maritime-cloud case suggests the same conclusions, except that the difference are less dramatic than between the two cases in the box model. For example, the decrease of the $\left[\mathrm{NO} / / \mathrm{NO}_{2}\right]$ ratio between the continental case and the maritime case is less important than between the two box model cases. Two main reasons can explain this difference:

Table 6. Deviations From Henry's Law for the Species $\mathrm{CH}_{3} \mathrm{O}_{2} \mathrm{H}, \mathrm{CH}_{2} \mathrm{O}, \mathrm{HO}_{2}$

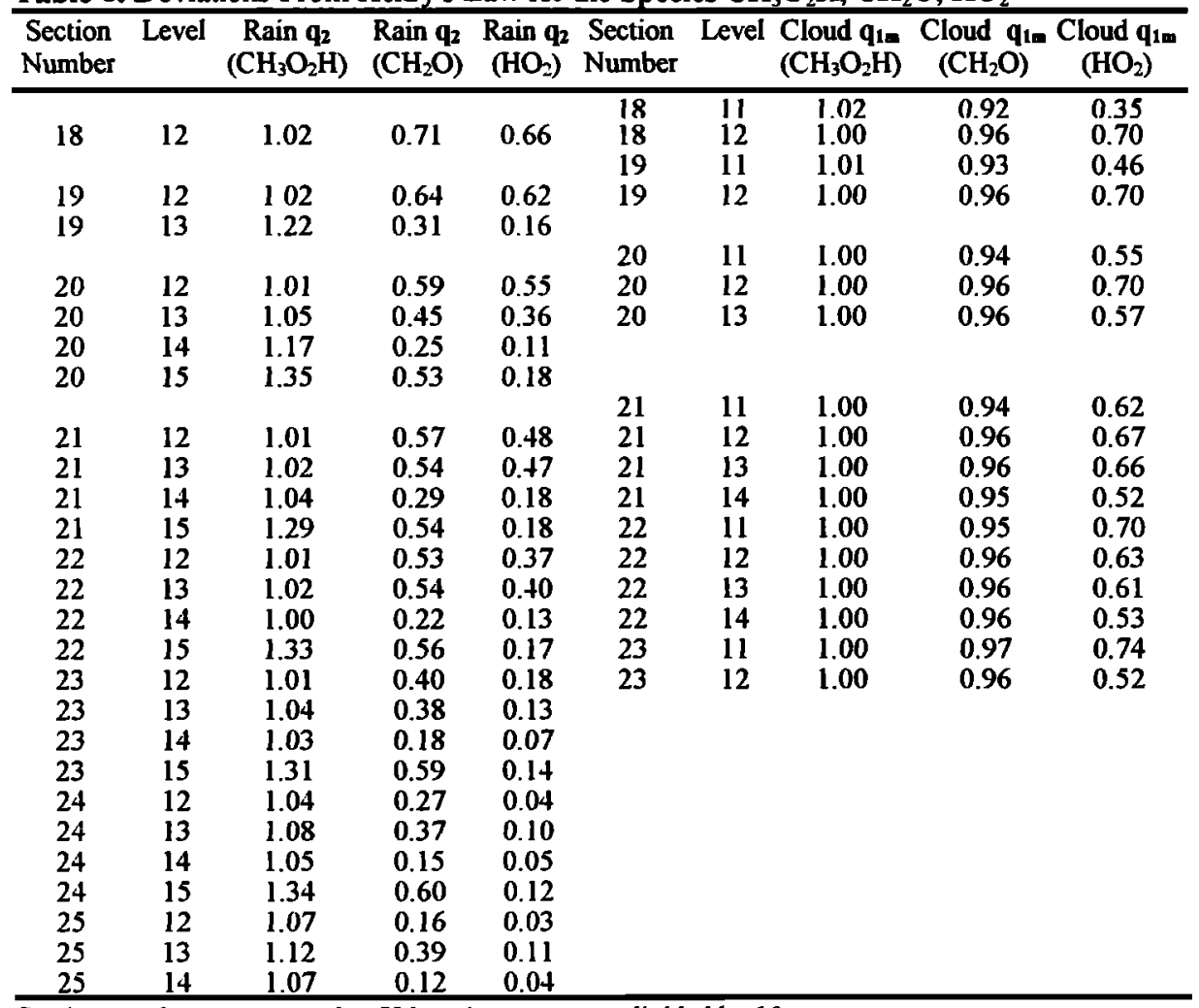

Section numbers correspond to $X$ location : see text; divided by 10

(levels $11,12,13,14$ and 15 represent the altitudes above the ground of $1165,765,395,165$ and $35 \mathrm{~m}$ ). 
(1) No precipitation in the box model, and (2) In the maritime case, the partitioning of total liquid water in to a small-drop population and a large-drop population with links between them (autoconversion, coalescence of droplets).

Hence, a box model which is unable to simulate microphysical processes overestimates modifications due to the presence of liquid water.

Species concentrations in rainwater also reflect the dependence on drop size. Aqueous $\mathrm{NO}$ and $\mathrm{NO}_{2}$ concentrations show no dependence on drop size, while soluble species have decreasing rain concentrations with increasing drop diameter. This confirms that variations of gaseous concentrations of $\mathrm{NO}$ and $\mathrm{NO}_{2}$ are only due to the depletions in gas phase of the radicals $\mathrm{HO}_{2}$ and $\mathrm{CH}_{3} \mathrm{O}_{2}$. Hence, although they are moderately soluble species, these species are sensitive to drop-size due to their transfer speed to aqueous phase $\left(L k_{t}\right.$ term) which depends strongly on the drop diameter.

Finally, the location within the cloud also has importance, leading to different results compared to these in the center of the cloud. This feature can easily be seen in the ratio representing the deviation from Henry's law equilibrium. On the edges and the bottom of the cloud, the deviation from Henry's law exists even in cloud water, while it disappears on the top of the mountain in the center of the cloud.

When rain is present, the deviation from Henry's law is also found in cloud water but is likely not due to an increase of gaseous concentrations by evaporation (as for cloud water) but rather a removal from cloud water content by conversion of droplets into raindrops. In rainwater, deviations from Henry's law reflect dependence on drop size for both $\mathrm{HCOOH}$ and $\mathrm{H}_{2} \mathrm{O}_{2} \cdot \mathrm{H}_{2} \mathrm{O}_{2}$ appears to be farther from Henry's law equilibrium in the continental case. The difference of behavior between $\mathrm{HCOOH}$ and $\mathrm{H}_{2} \mathrm{O}_{2}$ can be explained by their different solubilities but more importantly because the former is mainly produced in aqueous phase while the other in gas phase. The species mainly produced in the gas phase seem to be more sensitive to drop-size.

Finally, solely the very low soluble species follows the Henry's law. Peroxy radicals aqueous concentrations would be largely overestimated (30-40\%) if Henry's law is used to predict them.

This is due to an indirect effect of aqueous chemistry and this result highlights that aqueous chemistry is of considerable importance for the fate of these radicals and hence tropospheric chemistry.

Impacts of polydisperse clouds are not limited to this chemical species partitioning effect. Photolysis rates are also dependent on the microphysical properties of the cloud via the effective droplet radius which varies significantly depending on whether the cloud is monodisperse or polydisperse as a precipitating cloud. Our present study focuses on the partitioning effect and therefore the photolysis rate was kept constant. Effects on photolysis rates of polydisperse clouds will be studied in a following paper.

\section{Appendix}

The Kessler [1949] scheme is highly parameterized using one single prognostic variable for rain - the rainwater mixing ratio - $\mathrm{q}_{\mathrm{rw}}$, assuming a distribution of the raindrops given by the Marshall-Palmer [1948] spectrum. In contrast, the Berry-
Reinhardt scheme is semi-spectral, derived from results obtained by integrating a fully spectral microphysical scheme, including in particular the self-collection process. This latter, at the difference with processes of autoconversion and accretion, is not parameterized in the Kessler scheme. The Berry-Reinhardt scheme assumes a log-normal distribution for both cloud water and rainwater drop spectra. Therefore, in that scheme the additional predictive variable (for the rainwater mixing ratio) is the total number of raindrops $\mathrm{N}_{\mathrm{rw}}$, providing information on the evolution of the raindrop diameter.

In addition to the advantage of giving 2 degrees of freedom for the parameterization, the Berry-Reinhardt scheme allows the mass density function to vary during the simulation. In the case of a log-normal distribution, raindrops mass density distribution can be centered either on small or large diameters. Finally, the Berry-Reinhardt scheme enables partial evaporation which can play a non negligible role in the release of gas.

The microphysics are described by three prognostic variables : $q=q_{v}+q_{c w}$, the sum of water vapor and cloud water mixing ratios, $\mathrm{q}_{\mathrm{rvw}}$, the rainwater mixing ratio and $\mathrm{N}_{\mathrm{rw}}$ the total number of raindrops. The corresponding equations take the following form:

$$
\begin{aligned}
& \frac{d q}{d t}=-Q_{a u t}-Q_{a c c}+Q_{e v a} \\
& \frac{d q_{r w}}{d t}=Q_{a u t}+Q_{a c c}-Q_{e v a}+Q_{\text {sed }} \\
& \frac{d N_{r w}}{d t}=N_{a u t}-N_{\text {self }}+Q_{\text {sed }}
\end{aligned}
$$

where $Q$ and $N$ represent the various sources or sinks of mixing ratio and concentration, respectively. The subscript aut stands for autoconversion of cloud droplets into raindrops, acc for accretion of cloud droplets by raindrops and self for the self-collection of the raindrops. The subscripts eva and sed denotes the rain evaporation and sedimentation, respectively, (see Richard and Chaumerliac, [1989] for the details of these terms). The cloud water mixing ratio, $\mathrm{q}_{c w}$, is diagnosed from the predicted value of $q$. When supersaturation occurs with respect to liquid water, excess vapor is converted into liquid water.

Acknowledgments. The authors wish to thank and S. Cautenet for her helpful comments, P. Boudinhon and J. Squarise for technical assistance. This work was supported by funds from Electricité de France. Computer resources were provided by I.D.R.I.S (Institut du Développement et des Ressources en Informatique Scientifique), project $n^{\circ} 187$.

\section{References}

Berry, E.X. and R.L. Reinhardt, An analysis of cloud drops growth by collection, II. Single initial distributions, J. Atmos. Sci., 31, 1825-1831, 1974.

Cautenet, S., and B. Lefeivre, Contrasting behavior of gas and aerosol scavenging in convective rain: $A$ numerical and experimental study in the African equatorial forest, J. Geophys. Res., 99, 13,013-13,024, 1994.

Chang, J.S., R.A Brost., I.S Isaksen., S. Madronich, W.R. Stockwell and C.J. Walcek, A three-dimensional eulerian acid deposition model: Physical concepts and formulation, $J$. Geophys. Res., 92, 14,681-14,700, 1987.

Chaumerliac, N., E. Richard, J.P. Pinty, and E.C. Nickerson, Sulfur scavenging in a mesoscale model with quasi-spectral microphysics: $2 D$ results for continental and maritime clouds, $J$. Geophys. Res., 92, 3114-3126, 1987. 
Chaumerliac, N., E. Richard , R. Rosset and E.C. Nickerson, Impact of two microphysical schemes upon gas scavenging and deposition in a mesoscale meteorological model, $J$. Applied Meteorol., 30, 88-97, 1990.

Collett, J., B. Oberholzer and J. Staehelin, Cloud chemistry at Mt Rigi, Switzerland: dependence on drop size and relationship to precipitation chemistry, Atmos. Environ., 27A, (1), 33-42, 1993.

Dentener, F.J., and P.J.Crutzen, Reaction of $\mathrm{N}_{2} \mathrm{O}_{5}$ on tropospheric aerosols: impact on the global distribution of $\mathrm{NO}_{2}, \mathrm{O}_{3}$, and $\mathrm{OH}$. J. Geophys. Res., 98, 7149-7163,1993.

Grégoire, P.J., N. Chaumerliac and E.C. Nickerson, Impact of cloud dynamics on tropospheric chemistry: Advances in modeling the interactions between microphysical and chemical processes, J. Atmos. Chem., 18, 247-266, 1994.

Huret, N., N. Chaumerliac, H. Isaka, and E.C.Nickerson, Impact of different microphysical schemes on the prediction of dissolution of nonreactive gases by cloud droplets and raindrops, $J$. Applied Meteorol., 33, 1096-1109, 1994.

Jacob, D.J., Chemistry of $\mathrm{OH}$ in remote clouds and its role in the production of formic acid and peroxymonosulfate. J. Geophys. Res., 91, 9807-9826,1986.

Kessler, E., On the redistribution and continuity of water substance in atmospheric circulations, Meteorol. Monogr., 10, 32, 84pp., 1969.

Lelieveld J. and P.J. Crutzen, Influence of cloud photochemical processes on tropospheric ozone, Nature, 343, 227-233, 1990.

Lelieveld $J$ and P.J. Crutzen, The role of clouds in tropospheric photochemistry, J. Atmos. Chem., 12, 229-267, 1991.

Nickerson E.C., E. Richand, R. Rosset and D.R. Smith, The numerical simulation of clouds, rain and airflow over the Vosges and Black Forest mountains: a meso- $\beta$ model with parameterized microphysics, Mon. Wea. Rev., 23, 477-487, 1986.

Noone K.J., R.J. Charlson, D.S. Covert, J.A. Ogren and J. Heintzenberg, Cloud droplets: solute concentration is size dependent., J. Geophys. Res., 93, D8, 9477-9482, 1988.

Pandis S.N. and J.H. Seinfeld, On the interaction between equilibration processes and wet or dry deposition., Atmos. Environ., 24A, 2313-2327, 1990.

Pandis S.N. and J.H. Seinfeld, Should bulk cloudwater or fogwater samples obey Henry's law?, J. Geophys. Res., 96, D6, 10,791-10,798, 1991.

Pandis S.N. and J.H. Seinfeld, Reply to comments of Winiwarter et al., (1992) on * Should bulk cloudwater or fogwater samples obey Henry's law?, J. Geophys. Res., 96, D6, 10791-10798, 1991 *, J. Geophys. Res., 97, D5, 6079-6081, 1992.

Ponche, J.L., C. George, and P. Mirabel, Mass transfer at the air/water interface : Mass accommodation coefficients of $\mathrm{SO}_{2}$, $\mathrm{HNO}_{3}, \mathrm{NO}_{2}$ and $\mathrm{NH}_{3}$, Atmos. Chem., 16, 1-21, 1993.

Richard E. and N. Chaumerliac, Effects of different parameterizations on the simulation of mesoscale orographic precipitation., J. Applied Meteorol., 28, 1197-1212, 1989.

Schwartz S., Mass-transport considerations pertinent to aqueous phase reactions of gases in liquid water clouds, Chemistry of mulitphase systems, W.Jaeschke, Ed. Springer, 415-471,1986.

Sander R., J. Lelieveld, and P.J. Crutzen, Modelling of the nighttime nitrogen and sulfur chemistry in size resolved droplets of an orographic cloud, J. Atmos. Chem., 20, 89-116, 1995.

Seinfeld J.H., Atmospheric Chemistry and Physics of air Pollution, 738pp., John Wiley, New York, 1986.

Utter R.G., Burkholder J.B., Howard C.J., and A.R. Ravishankara, Measurements of the mass accommodation coefficient of ozone on aqueous surface, J. Phys. Chem., 96, 4973-4979, 1992.

Van Doren J., Watson L.R., Davisovits P., Worsnop D.R., Zahniser M.S., and C.E. Kolb, Temperature dependence of the uptake coefficients of $\mathrm{HNO}_{3}, \mathrm{HCl}$, and $\mathrm{N}_{2} \mathrm{O}_{5}$ by water droplets, J. Phys. Chem., 94, 3265-3269, 1990.

Winiwarter W., H. Puxbaum, S. Fuzzi, M.C. Facchini, G. Orsi, N. Beltz, K. Enderle, and W. Jaeschke, Organic acid gas and liquid measurements in Po Valley fall-winter conditions in the presence of fog., Tellus, 4OB, 348-357, 1988.

Winiwarter W., B. Brantner and H. Puxbaum, Comment on " Should bulk cloud water or fogwater samples obey Henry's law?" "by S.N. Pandis and J.H. Seinfeld., J. Geophys. Res., 97, D5, 6075-6078, 1992.

Worsnop D.R., M.S. Zahniser, C.E. Kolb, J.A. Gardner, L.R. Watson, J.M. Van Doren, J.T. Jayne, and P. Davidovits, Temperature dependence of mass accommodation of $\mathrm{SO}_{2}$ and $\mathrm{H}_{2} \mathrm{O}_{2}$ on aqueous surface, J. Phys. Chem., 93, 1159-1172, 1992.

N. Audiffren, N. Chaumerliac, E. Renard, Laboratoire de Météorologie Physique, Observatoire de Physique du Globe de Clermont-Ferrand, CNRS/Université Blaise Pascal, 24 Avenue des Landais, 63177 Aubière Cedex, France. (e-mail: audiffre@opgc.univbpclermont.fr, chaumerl@opgc.univ-bpclermont.fr)

(Received October 12, 1995; revised April 13, 1995; accepted May 10, 1996) 